\title{
SINGULARIDADES PROCESALES Y PROBLEMAS PRÁCTICOS DE LA LEY DE RESPONSABILIDAD PENAL DEL MENOR*
}

\author{
Juan de la Cruz OCÓN GARCÍA \\ BECARIO DE COLABORACIÓN DEL DEPARTAMENTO DE DERECHO \\ UNIVERSIDAD DE LA RIOJA
}

SumARIO: I. Ámbito subjetivo de aplicación. II. Sujetos intervinientes. II.r. El Juez de Menores. II.I.I. Competencias. II.r.2. Especialización. II.2. El Ministerio Fiscal. II.3. El Equipo Técnico. II.4. El menor imputado y su defensa. II.4.I. El menor. II.4.2. El abogado defensor. II.5. La víctima: de coadyuvante sin acción a acusación particular. II.5.I. El régimen originario de la LORPM: participación del perjudicado en el proceso de menores. II.5.2. La introducción de la acusación particular por la LO I5/2003. III. El régimen especial de la responsabilidad civil. III.I. Competencia. III.2. Legitimación. III.2.I. Activa. III.2.2. Pasiva. III.3. Postulación. III.4. Procedimiento. III.4.I. El procedimiento instaurado por la LORPM. III.4.2. Tratamiento procesal de la responsabilidad civil tras la LO 8/2006. IV. Breve referencia al enjuiciamiento de delitos cometidos por mayores y menores conjuntamente.

RESUMEN: Con la aprobación de la Ley Orgánica 5/2000, de I2 de enero, reguladora de la responsabilidad penal de los menores se dio respuesta a las exigencias que, en materia de justicia juvenil, derivaban de los textos internacionales, como, principalmente, la preeminencia del interés del menor. Sin embargo, las sucesivas reformas a las que se vio sometida fueron desfigurando su silueta hasta hacerla casi irreconocible. En el presente artículo se abordan, por un lado, las especialidades que respecto del proceso de adultos se han introducido en el proceso penal de menores, bien necesariamente por dimanar del interés del menor, bien como simples opciones de política criminal, y, por otro, los aspectos más problemáticos de la Ley, derivados en gran parte de sus continuas reformas.

PALABRAS ClAVE: responsabilidad penal de los menores, delincuencia juvenil, menores infractores, justicia juvenil, proceso penal.

ABSTRACT: the adoption of Organic Law 5/2000 of I2 January, which regulates the criminal liability of minors, constituted a response to the requirements, in the matter of juvenile justice, derived from international texts as, mainly, the pre-eminence of the interests of the minor. Nevertheless, the successive amendments made were distorting its figure to the point of making it unrecognizable. This article addresses, on the one hand, the specialties with regard to the proceeding of adults that have been introduced in the criminal proceedings for minors either for stemming from the interests of the minor or as simple options for criminal policy and, on the other hand, the most problematic aspects of the law as a result of its continuous amendments.

KEYwORDS: criminal liability of minors, juvenile delinquency, young offenders, juvenile justice, criminal proceedings.

\footnotetext{
* Extracto del trabajo fin de grado «Iter legislativo, singularidades y problemas prácticos del proceso penal de menores en España» (texto íntegro disponible en: http://biblioteca.unirioja.es/tfe_e/TFEooo568.pdf).
} 


\section{I. Ámbito subjetivo de aplicación}

El Código Penal de I995 estableció en su art. I9 la irresponsabilidad penal de los menores de dieciocho años con arreglo a él, siendo de aplicación a los menores de esa edad que delinquiesen, en su caso, lo que dispusiera una ley que debía regular la responsabilidad penal de los menores. Igualmente, el art. $69 \mathrm{CP}$ previó la posibilidad de aplicar el contenido de esa ley de menores a los mayores de dieciocho años y menores de veintiuno en los casos y con los requisitos que ella dispusiere.

Pues bien, la Ley Orgánica 5/2000, de I2 de enero, reguladora de la responsabilidad penal de los menores (en adelante LORPM) fijó su ámbito de aplicación (art.I.I) en la exigencia de responsabilidad de los mayores de catorce años y menores de dieciocho por la comisión de hechos tipificados como delitos o faltas en el CP o en las leyes penales especiales. Con la fijación de un límite de edad, siguiendo las pautas del modelo biológico puro, se introduce un criterio de seguridad jurídica, ajustándose a las previsiones de la Convención de los Derechos del Niñor.

Lo previsto en el art. 69 CP quedó reflejado en el art. I.2. LORPM, que posibilitaba su aplicación a los mayores de dieciocho años y menores de veintiuno en los términos establecidos en su art. 4.

En este escenario pueden distinguirse cuatro periodos en cuanto al ámbito de aplicación de la LORPM: niños, menores, jóvenes y adultos.

I) Los niños - menores de catorce años- son irresponsables penalmente, aplicándoseles lo dispuesto en las normas sobre protección de menores y debiendo el Ministerio Fiscal remitir a la entidad pública de protección testimonio de los particulares que considere de interés al objeto de adoptar las medidas de protección que se estimen adecuadas (art. 3 LORPM).

2) Los menores — de catorce a dieciocho años- son responsables conforme a la LORPM, siendo estos sus principales destinatarios. Dentro de este periodo se diferencian dos grupos etarios, de catorce a dieciséis y de dieciséis a dieciocho años, en los que se aplica una diferente graduación de las consecuencias por los hechos cometidos.

3) Los jóvenes - mayores de dieciocho años y menores de veintiuno- son, como regla general, responsables con arreglo al CP, pero para determinados supuestos y concurriendo ciertas condiciones ${ }^{2}$ se preveía la aplicación del Derecho penal juvenil ${ }^{3}$. Sin embargo, las sucesivas reformas hicieron que esta posibilidad nunca pudiese llegar a ser aplicada.

\footnotetext{
${ }^{1}$ Miranda Estrampes, M., «Aspectos procesales de la nueva Ley reguladora de la Responsabilidad Penal del Menor (I)», Revista Xurídica Galega, 30, 200I, pág. 36 (disponible en: http://www.rexurga.es/; fecha de consulta: 26.V.20I4).

${ }^{2}$ Las condiciones que establecía el art. 4 LORPM eran las siguientes: I. Que el imputado hubiere cometido una falta, o un delito menos grave sin violencia o intimidación en las personas ni grave peligro para la vida o la integridad física de las mismas. 2. Que no haya sido condenado en sentencia firme por hechos delictivos cometidos una vez cumplidos los dieciocho años. 3. Que las circunstancias personales del imputado y su grado de madurez aconsejen la aplicación de la presente Ley, especialmente cuando así lo haya recomendado el equipo técnico en su informe.

${ }^{3}$ Serrano Tárraga, M.D. y Vázquez González, C., Derecho penal juvenil, Ia edición, Madrid, Dykinson, 2005, pág. 239.
} 
El problema de este aspecto reside en la reforma producida por la LO 8/2006, y es que, debido a un descuido del legislador, entre el fin de la última prórroga de suspensión de la vigencia del art. 4 LORPM - I de enero de 2007- y la entrada en vigor de la ley de 2006 que lo suprime -5 de febrero de 2007 - nos encontramos con un periodo en que sí estuvo vigente, lo que suscitó múltiples dudas y reacciones.

La primera reacción llegó de la Fiscalía General del Estado que, en Instrucción 5/2006, de 20 de diciembre, concluía señalando que la suspensión del art. 4 hasta el I de enero de 2007 debía entenderse tácitamente prorrogada hasta que adquiriese vigencia la nueva norma y, como consecuencia, animaba a los fiscales a oponerse a la aplicación del precepto y a recurrir las resolución judiciales que lo aplicasen.

El Consejo General de Abogacía se pronunció de forma contraria, recomendando a los letrados que solicitarán, a través del oportuno incidente, la aplicación del art. 4 LORPM ${ }^{4}$. En sentido similar se manifestó la Audiencia Provincial de Madrid que consideró vigente el precepto en ese periodo de tiempo y, por tanto, aplicable a los hechos cometidos en él y a los anteriores en los que no hubiese recaído condena en sentencia firme, en virtud del principio de retroacción de la norma más favorable 5 .

Sin embargo, para SILVA SÁNCHEZ ${ }^{6}$ también sería aplicable la LORPM para los casos en que, existiendo condena en sentencia firme anterior al I de enero de 2007 , la pena se hallase en ejecución, debiendo ser revisada en virtud del art. 2.2 CP

Finalmente, la cuestión fue resuelta por STS de 4 de junio de 2007 -a la que siguieron otras de 13 de junio de 2007 y de 25 de noviembre de 2008 - que, acogiendo el criterio de la Fiscalía, consideró que ante el craso error material del legislador debía entenderse prorrogada la suspensión tácitamente hasta la entrada en vigor de la nueva norma.

4) Por último, los adultos — mayores de veintiuno- serán en todo caso responsables penalmente según el CP.

\section{Sujetos intervinientes}

II.I. El Juez de Menores

\section{II.I.I. Competencias}

A diferencia de lo que ocurre en el proceso penal de adultos, el Juez de Menores no efectúa la instrucción, que se encomienda al Ministerio Fiscal. Sin embargo, su intervención no queda limitada a dirigir la fase de audiencia y dictar la resolución, sino que también participa en la fase de instrucción y en la fase intermedia. Así, corresponde al Juez de Menores durante la investigación acordar el secreto del expediente (art. 24 LORPM),

${ }^{4}$ Circular 5/2007, de 4 de enero, del Consejo General de la Abogacía Española.

${ }^{5}$ Acuerdos de unificación de criterios del orden penal de la Audiencia Provincial de Madrid, en relación con la problemática derivada del art. 4 LORPM, de I2 de enero de 2007.

6 Silva SÁnChEZ, J.M., «"Rebajas de enero” para delincuentes jóvenes adultos ¿con efecto retroactivo?», InDret, I, 2007, pág. 7 (disponible en: http://www.indret.com/pdf/400_es.pdf; fecha de consulta: 02.VI.20I4).

${ }^{7}$ «[...] tendrán efecto retroactivo aquellas leyes penales que favorezcan al reo, aunque al entrar en vigor hubiera recaído sentencia firme y el sujeto estuviese cumpliendo condena». 
practicar las diligencias restrictivas de derechos fundamentales (arts. 23.3 y 26.3 LORPM) y resolver sobre la adopción de las medidas cautelares que se soliciten (art. 28 LORPM).

Mayores problemas presenta la participación del Juez de Menores en la fase intermedia, a quien corresponde decidir sobre la celebración de la audiencia o el sobreseimiento y practicar las pruebas propuestas por las partes y denegadas por el Fiscal durante la instrucción (art. 33 LORPM).

Por lo que se refiere al primero de los problemas, la decisión sobre celebrar la audiencia o sobreseer las actuaciones, entiende MIRANDA ESTRAMPES que «no es un mero acto de ordenación forma del proceso, sino que su naturaleza presenta similitudes con el auto de apertura del juicio oral del Procedimiento Abreviado» y que, por tanto, «el Juez de Menores debe realizar un juicio anticipado y provisional sobre la calificación de los hechos y la culpabilidad de los menores acusados». En este sentido, la STC 60/1995, de I7 de marzo ${ }^{9}$, que resuelve varias cuestiones de inconstitucionalidad contra la Ley Orgánica 4/1992, de 5 de junio, reguladora de la competencia y el procedimiento de los Juzgados de Menores (en adelante LORCPJM), descarta que la acumulación en un mismo órgano de la fase intermedia y el juicio oral implique una violación del derecho al Juez imparcial. Sin embargo, la posterior STC 310/2000, de I8 de marzo ${ }^{\mathrm{Io}}$, entendió que «la intervención del Juez con carácter previo al enjuiciamiento de los hechos, al dictar el Auto de apertura del juicio oral, hizo quebrar su neutralidad, al ser necesario a tal efecto apreciar la existencia de indicios racionales de criminalidad».

En cuanto a la posibilidad del Juez de Menores de practicar por sí las pruebas denegadas en instrucción por el Ministerio Fiscal, entiende Miranda Estrampes que estamos ante verdaderas diligencias de investigación, por lo que el juzgador entra en contacto directo con las fuentes de prueba, desarrollando una instrucción judicial complementaria y quedando necesariamente «contaminado».

\section{II.I.2. Especialización}

Para la provisión de los Juzgados de Menores se exige la categoría de magistrado, teniendo preferencia quienes acrediten la correspondiente especialización en materia de menores en la Escuela Judicial (art. 329 LOPJ). En todo caso, la LOPJ trata de garantizar la especialización de los Jueces de Menores ya que, quienes obtengan la plaza, deben participar antes de la toma de posesión en las actividades de especialización en materia de menores que establezca el CGPJ.

Aunque el texto originario preveía la creación de Salas de Menores en los TSJ servidas por magistrados especialistas para conocer de los recursos de apelación, la supresión de estas por la LO 9/2000 y la atribución de sus competencias a las Audiencias Provinciales no se acompañó de requisito alguno de especialización ni del establecimiento de Secciones especiales en ellas ${ }^{12}$.

\footnotetext{
${ }^{8}$ Miranda Estrampes, M., «Aspectos procesales... (I)», cit., pág. 5 I.

${ }^{9}$ BOE $n^{\circ} 98$, de 25 de abril de I995.

${ }^{\text {Io }}$ BOE $\mathrm{n}^{\circ} \mathrm{I} 4$, de $\mathrm{I} 6$ de enero de $200 \mathrm{I}$.

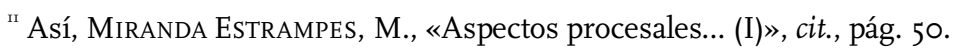

${ }^{12}$ Morenilla Allard, P., El proceso penal del menor: Actualizado a la LO 8/2006 de 4 de diciembre, $\mathrm{I}^{\mathrm{a}}$ edición, Madrid, Colex, 2007, pág. 69.
} 
Esto dio lugar a la cuestión de inconstitucionalidad núm. 3792-200I, planteada por el Juzgado de Menores núm.I de Valencia por entender, entre otros extremos, que el hecho de que los intervinientes en el proceso no sean especialistas en menores podría dar lugar a la inconstitucionalidad del art. 4I LORPM, por vulnerar el derecho a la tutela judicial efectiva del art. 24 CE en relación con los arts. 37. d) y 40 CDN. Sin embargo, la STC I46/20I2, de 5 de julio ${ }^{\text {I3 }}$, que se ocupa de resolver la citada cuestión, no entra al fondo de este asunto, ya que rechaza a limine la cuestión en relación con el art. 4I LORPM por entender que no depende de ello la resolución del caso, no siendo por tanto la cuestión de inconstitucionalidad el cauce procesal oportuno (art. 37.I LOTC).

\section{II.2. El Ministerio Fiscal}

En la jurisdicción de menores se ha pasado de una situación de tradicional ausencia del Ministerio Fiscal a convertirse, con la LORPM, en pieza esencial para hacer realidad sus previsiones $^{\mathrm{I} 4}$. Aunque con la Instrucción de la FGE 2/I992, de I3 de febrero, dictada a consecuencia de la STC de I99I, ya se vislumbraba la posibilidad de poner la instrucción en manos del Ministerio Fiscal ${ }^{15}$, fue la LORCPJM la que instauró este nuevo sistema. La LORPM renueva la confianza que aquella depositó en el Fiscal y lo convierte en un órgano plurifuncional al que, además de dirigir la investigación, le corresponde la defensa de los derechos de los menores, la observancia de las garantías del procedimiento y su impulso y, obviamente, la función de parte acusadora en el juicio oral.

La LORPM otorga al Ministerio Fiscal el papel de «Director de la Investigación», correspondiéndole, en este sentido, acordar la práctica de las diligencias instructoras dirigidas a investigar el hecho punible y la participación en él del menor, es decir, le corresponde la función de preparar el juicio oral o proponer al Juez el sobreseimiento ${ }^{16}$.

Para DÍAZ MARTínEZ, la opción adoptada por el legislador de atribuir la instrucción al Ministerio Fiscal bajo el control del Juez de Menores es la que mejor refleja el nuevo orden jurídico instaurado por la CE de $1978^{17}$ : nuestra Carta Magna establece el principio de exclusividad de la jurisdicción, fijando su contenido positivo - juzgar y hacer ejecutar lo juzgado (art. II7.3 CE) - y sus límites negativos — los Juzgados y Tribunales no ejercerán más funciones que las señaladas en el apartado anterior y las que expresamente les sean atribuidas por ley en garantía de cualquier derecho (art II7.4 CE)—. De lo anterior deduce el autor dos consecuencias: de un lado, que en la investigación penal no se produce ejercicio de la potestad jurisdiccional y, de otro, que no resulta necesaria la intervención judicial en

\footnotetext{
${ }^{13}$ BOE $\mathrm{n}^{\mathrm{o}} \mathrm{I} 8 \mathrm{I}$, de 30 de julio de 2012.

${ }^{\text {I4 }}$ Circular de la Fiscalía General del Estado I/2000, de I8 de diciembre.

${ }^{15}$ «De momento, esta Fiscalía General no considera oportuno que los Fiscales tomen a su cargo la instrucción de los expedientes, mientras no exista una ley que nos legitime para ello. Pero como esta postura podría dar lugar a que el Juez de Menores se "contamine”, dificultándole o impidiéndole dictar el acuerdo final, los señores Fiscales procurarán que la instrucción se limite a lo mínimo imprescindible, potenciando la oralidad e inmediación en la probanza, dando sí una mayor agilidad al procedimiento».

${ }^{16}$ Díaz Martínez, M., La instrucción en el proceso penal de menores, Ia edición, Madrid, Colex, 2003, pág. 93.

${ }^{17}$ Díaz Martínez, M., «El Ministerio Fiscal “Director de la Investigación” en el Proceso Penal de Menores», en Gimeno Sendra, V., El Ministerio Fiscal - Director de la Instrucción, Iª edición, Madrid, Iustel, 2006, pág. 54.
} 
todo momento de la investigación penal sino simplemente a título de garante de los derechos fundamentales de las partes y juzgadores del objeto material de la acusación ${ }^{\text {r8 }}$.

Algunos autores han apuntado como este modelo instaurado en la jurisdicción de menores puede obedecer a su utilización como banco de pruebas para la futura reforma de la LECrim en el proyectado Código Procesal Penal de 20I3, al objeto de incorporar al proceso penal de adultos la figura del Fiscal investigador ${ }^{\text {19 }}$.

En cuanto al papel clásico de parte acusadora que ostenta el Ministerio Fiscal, cabe aquí recordar que, si bien en la redacción original de la LORPM ejercía este rol en régimen de monopolio, ahora es compartido ya que las reformas de 2003 y 2006 introducen y desarrollan, respectivamente, la figura de la acusación particular. No obstante, el Fiscal mantiene el monopolio en el ejercicio de la acción penal en su vertiente más relevante de acceso a la jurisdicción penal, al ser el único titular de la facultad discrecional de no incoar el procedimiento (art. I8 LORPM); con la singularidad, además, de que los decretos pronunciados por él no son recurribles ${ }^{20}$.

\section{II.3. El Equipo Técnico}

La LORPM establece su epicentro en el interés superior del menor, declarando su Exposición de Motivos que dicho interés «ha de ser valorado con criterios técnicos y no formalistas por equipos de profesionales especializados en el ámbito de las ciencias no jurídicas».

La apreciación de las circunstancias que han incidido en la conducta delictiva del menor y el diagnóstico de su situación personal, familiar y social requiere unos conocimientos en psicología y psiquiatría forense, en pedagogía, entorno familiar y asistencia social que exigen una especialización científica ${ }^{2 \mathrm{~T}}$. El Juez y el Fiscal de Menores han de contar con el asesoramiento profesional en estas materias durante el curso del proceso y, especialmente, en la adopción y ejecución de las medidas, lo que se confía a los denominados Equipos Técnicos, cuyo papel en el proceso penal de menores es tan importante que han sido calificados como «elemento vertebrador de la Ley» ${ }^{22}$.

Como antecedentes de estos equipos encontramos, ya en la primera Ley de Tribunales para Niños de I9ı8, los «delegados de protección de la infancia». La LOPJ de I985 contempló la existencia de profesionales y expertos para auxiliar a los Juzgados y Tribunales (art. 508), llevándose a cabo la implantación de facto de «equipos técnicos de apoyo» desde I988. Finalmente, la LORCPJM introdujo en 1992 la actuación en todos los

\footnotetext{
${ }^{18}$ Sobre el tema puede verse: Nieto Luengo, M., «Beneficios e inconvenientes (perjuicios) de la instrucción del proceso penal de menores por el Ministerio Fiscal», RDUNED, 8, 20II, págs. 333-350 (disponible en: http://e-spacio.uned.es/fez/view.php?pid=bibliuned:RDUNED-20II-8-5IIo; fecha de consulta: 26.V.20I4).

${ }^{19}$ Miranda Estrampes, M., «Aspectos procesales... (I)», cit., pág. 46. Igualmente, Polo Rodríguez, J.J., y HuÉlamo Buendía, A.J., hablan de "experiencia piloto" en La nueva ley penal del menor, $\mathrm{I}^{\mathrm{a}}$ edición, Madrid, Colex, 2000, pág. I5.

${ }^{20}$ Morenilla Allard, P., El proceso penal del menor..., cit., pág. 77.

${ }^{21}$ Ibíd., pág. 89.

${ }^{22}$ Rodríguez PÉReZ, J.P., «Algunas peculiaridades del proceso penal de menores», Anales de la Facultad de Derecho, 2I, 2004, pág. I78 (disponible en: http://publica.webs.ull.es/publicaciones/volumen/anales-de-lafacultad-de-derecho-volumen-2I-2004/; fecha de consulta: 26.V.20I4).
} 
procesos de los Juzgados de Menores del equipo técnico, ampliando la LORPM su intervención en el proceso y definiendo su actuación con mayor precisión ${ }^{23}$.

Como función principal corresponde al Equipo Técnico, en sede de instrucción, la elaboración de un informe sobre la situación psicológica, educativa y familiar del menor, así como sobre su entorno social y otras circunstancias relevantes para la adopción de las medidas (art. 27.I LORPM). Además, la LORPM confiere al Equipo Técnico otras diversas funciones que se pueden agrupar en las siguientes: I) asistir personalmente a los menores a lo largo del proceso, lo que se configura como un derecho de éstos (art. 22.I.f LORPM); 2) emitir su opinión antes de que el Juez adopte ciertas decisiones sobre el menor - medidas cautelares (art. 28.I LORPM), suspensión de la ejecución del fallo (art. 40.I LORPM), o sustitución o extinción de la medida impuesta (arts. 50.2 y 5I.3 LORPM) —; 3) desempeñar labores de mediación a efectos de la posible conciliación y reparación (art. I9.3 LORPM); y 4) intervenir en la audiencia y, en su caso, en la vista del recurso de apelación (arts. 35.I y 4I.I LORPM $)^{24}$.

Por lo que se refiere a la composición de estos equipos técnicos, no quedó configurada hasta la llegada del Real Decreto I774/2004, de 30 de julio, por el que se aprueba el Reglamento de la Ley Orgánica 5/2000, de I2 de enero, reguladora de la responsabilidad penal de los menores (en adelante RLORPM) ${ }^{25}$. En su art. 4.I establece que los equipos técnicos estarán formados por psicólogos, educadores y trabajadores sociales, recogiendo así lo que ya se venía haciendo en la práctica y configurándolos como un órgano colegiado multidisciplinar formado por especialistas técnicos de lo psico-social $^{26}$.

Estos equipos están adscritos a los Juzgados de Menores, si bien, durante la instrucción del expediente, desempeñarán su trabajo bajo la dependencia funcional del Ministerio Fiscal (art. 4.2 RLORPM).

Mayor complejidad ofrece la delimitación de la naturaleza y carácter de sus miembros ya que, si bien la originaria Disposición Final $3^{a} \cdot 5$ LORPM instaba al Gobierno a adoptar las disposiciones oportunas para la creación de Cuerpos de Psicólogos, y Educadores y Trabajadores Sociales Forenses, lo que hubiera permitido incluirlos dentro del «personal al servicio de la Administración de Justicia», la LO 9/2000 suprimió tal previsión. Así, para MORENILla AlLARD su régimen de incompatibilidades, excusas y recusación deberá ser el previsto para los peritos por la LECrim, dado su carácter supletorio $^{27}$. Sin embargo, Mingo BASAíl entiende que no se pueden considerar propiamente como peritos, sino más bien como asistentes técnicos del Tribunal, entendiéndose de forma más amplia que la pericia, como un elemento auxiliar del juez que desempeña sus servicios de forma estable ${ }^{28}$.

\footnotetext{
${ }^{23}$ Mingo BASAíl, M.L., «Psicólogos, educadores sociales y trabajadores sociales en los juzgados de menores. La actuación del equipo técnico», Indivisa: Boletín de estudios e investigación, 6, 2005, págs. II9 y ss. (disponible en: http://www.redalyc.org/pdf/771/77I00608.pdf; fecha de consulta: 06.VI.20I4).

${ }^{24}$ Ibíd, pág. I23.

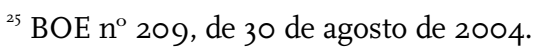

${ }^{26}$ Mingo BASAíl, M.L., «Psicólogos, educadores sociales...», cit., pág. I4O.

${ }^{27}$ Morenilla Allard, P., El proceso penal del menor..., cit., pág. 9I.

${ }^{28}$ Mingo BASAíl, M.L., «Psicólogos, educadores sociales...», cit., pág. I44.
} 
II.4. El menor imputado y su defensa

II.4.I. El menor

El menor es el verdadero protagonista del proceso, la parte pasiva del mismo, frente a quien se pide la actuación del ius puniendi del Estado. La ley parte de la consideración del menor como sujeto de derechos (art. I.2 LORPM), en línea con lo proclamado por los textos internacionales y la Ley Orgánica I/1996, de I5 de enero, de protección jurídica del menor (en adelante LOPJM) ${ }^{29}$.

El «expedientado», en tanto parte pasivamente legitimada, no sólo ostenta los mismos derechos y garantías procesales que el imputado o acusado en el proceso penal de adultos, sino, además, otros derechos «típicos» de su minoría de edad, de naturaleza procesal y asistencial, que comparte con sus padres, tutores o guardadores ${ }^{30}$.

El art. 22 LORPM recoge los derechos que ostenta el menor desde el mismo momento de la incoación del expediente: los derechos de carácter procesal son los recogidos en las letras a) a d) del art. 22.I y en el art. 22.2 LORPM, esto es, ser informado de los derechos que le asisten; designar abogado y entrevistarse reservadamente con él; intervenir en las diligencias que se practiquen, así como proponer la práctica de las mismas; ser oído por el Juez antes de adoptar cualquier resolución que le afecte; y el derecho a que se le notifique el expediente desde el mismo momento de su incoación.

Por otra parte, el art. I7 LORPM recoge los derechos del menor detenido, que son los que se enumeran en el art. 520 LECrim y otros específicos para asegurar la separación del menor de los detenidos adultos.

Los derechos más específicos del menor son los de naturaleza asistencial: la asistencia afectiva y psicológica en cualquier estado y grado del procedimiento, con la presencia de los padres o de otra persona que indique el menor, si el Juez de Menores autoriza su presencia (art. 22.I.e LORPM) y la asistencia de los servicios del equipo técnico adscrito al Juzgado de Menores (art. 22.I.f LORPM) $)^{31}$.

\section{II.4.2. El abogado defensor}

Dejando atrás la ausencia de abogado defensor en el proceso penal de menores, característica de la Ley de Tribunales Tutelares de Menores (en adelante LTTM), y al igual que sucede en el proceso penal de adultos, la LORPM, con el fin de dotar al derecho de defensa de la significación que le otorga el art. 24 CE, anticipa de modo inequívoco la designación por el imputado de Abogado a la fase instructora. De esta forma, dispone que, desde el mismo momento de la incoación del expediente, el menor tendrá derecho a designar Abogado que le defienda, o que le sea designado de oficio y a entrevistarse reservadamente con él, incluso antes de prestar declaración ${ }^{32}$.

Los actos del abogado defensor durante la instrucción están dirigidos a acreditar la inexistencia del hecho, su falta de tipicidad o de participación en él del menor o la

\footnotetext{
${ }^{29}$ Miranda Estrampes, M., «Aspectos procesales... (I)», cit., pág. 53.

${ }^{30}$ Morenilla Allard, P., El proceso penal del menor..., cit., pág. 8I.

${ }^{3 \mathrm{I}}$ Ibíd., pág. 82.

${ }^{32}$ Serrano Tárraga, M.D. y Vázquez GonZÁlez, C., Derecho penal juvenil, cit., pág. 253.
} 
concurrencia de alguna causa de exención de la responsabilidad penal o, en su caso, a demostrar la concurrencia de circunstancias psicológicas, educativas, sociales o familiares que puedan aconsejar desistir del procedimiento o alcanzar una solución extrajudicial. Esta es la razón por la que el art. 26.I LORPM permite al Abogado del menor solicitar del Ministerio Fiscal la práctica de cuantas diligencias considere necesarias ${ }^{33}$. Así, el letrado del menor se constituye en un nuevo elemento de protección del interés del menor, incluso en la fase instructora en la que el Ministerio Fiscal ha de desempeñar esta función no sólo con imparcialidad, sino también como protector de aquel interés.

De igual forma, la asistencia del Abogado defensor se hace necesaria con carácter previo a la incoación del expediente, desde el momento en que se produce la detención del menor; ya que el art. I7.2 LORPM precisa que toda declaración del detenido se lleve a cabo en presencia de su letrado ${ }^{34}$.

Por otro lado, la Disposición Final cuarta LORPM efectúa un mandato expreso al Consejo General de la Abogacía ordenándole que adopte las disposiciones oportunas para que en los Colegios se impartan cursos homologados para la formación de los letrados que vayan a intervenir ante los órganos de la jurisdicción de menores, a fin de recibir la especialización necesaria en la materia. Como respuesta a lo anterior, la Comisión del CGAE, por acuerdo de 28 de abril de 2000 , reguló el contenido mínimo exigible para la homologación de los cursos de especialización ${ }^{35}$.

II.5. La víctima: de coadyuvante sin acción a acusación particular

II.5.I. El régimen originario de la LORPM: participación del perjudicado en el proceso de menores

La LORPM, respondiendo fundamentalmente al interés superior del menor, prohibió inicialmente la acusación particular. No obstante, frente al clásico olvido de la víctima en la jurisdicción de menores, el art. 25 LORPM articuló un sistema de intervención de los perjudicados en el proceso con el objetivo de lograr un difícil equilibrio entre el interés del menor, el de la víctima y el de la sociedad ${ }^{36}$.

El citado precepto llevaba como rúbrica «Participación del perjudicado e inexistencia de acción particular y popular» y, debido a la confusión que ello puede generar, conviene aquí tratar de hacer una aclaración terminológica. La doctrina penal y procesal distinguen los conceptos «ofendido» y «perjudicado»: mientras que el primero es el titular del bien o interés tutelado por la norma penal transgredida, es decir, el sujeto pasivo del delito, el segundo es quien sufre en su esfera patrimonial los efectos nocivos de la acción delictiva. En la mayoría de los casos coinciden en una sola persona ambas circunstancias, pero en ocasiones pueden ser personas distintas ${ }^{37}$. La distinción de ambos conceptos tiene

\footnotetext{
${ }^{33}$ Ibíd., pág. 254.

${ }^{34}$ Morenilla Allard, P., El proceso penal del menor..., cit., pág. 84.

${ }^{35}$ Ponz Nomdedéu, E.V., «La responsabilidad penal de los menores desde la perspectiva del abogado», en Gómez Colomer, J.L. (Coord.), Justicia penal de menores y jóvenes: (análisis sustantivo y procesal de la nueva regulación), $\mathrm{I}^{\mathrm{a}}$ edición, Valencia, Tirant lo Blanch, 2002, pág. 382.

${ }^{36}$ Sanz Hermida, A.M., El nuevo proceso penal del menor, $\mathrm{I}^{\mathrm{a}}$ edición, Cuenca, Universidad de Castilla-La Mancha, 2002, pág. I66.

${ }^{37}$ Así, por ejemplo, si un representante de joyería lleva muestrarios que son propiedad del fabricante y le son hurtados, no cabe duda de que el ofendido es el representante y el perjudicado el fabricante. Vid. NoGUEIRA
} 
importancia práctica, ya que el ofendido tiene legitimación activa para el ejercicio de la acción penal, mientras que el perjudicado la tiene para el ejercicio de la acción civil.

Pues bien, estando clara la diferencia existente entre estas dos cualidades, y sabiendo que el art. 25 LORPM hablaba de «perjudicado», encontramos diversas interpretaciones. Para RODRIGUEZ PÉREZ es claro que el art. 25 al hablar de perjudicado se estaba refiriendo al que ejercita la pretensión civil, no sólo con base en una interpretación literal sino porque además el propio artículo prohibía expresamente la intervención del ofendido por el hecho delictivo al prohibir la acusación particular ${ }^{3^{8}}$. Para SANZ HERMIDA, en cambio, con la expresión «perjudicado» hay que entender que se hace referencia tanto al ofendido por el ilícito penal como al perjudicado por haber sufrido algún daño patrimonial como consecuencia del mismo ${ }^{39}$. Para decantarse por una $u$ otra interpretación entiendo que puede ser útil atender a la voluntad del legislador quien, en la Exposición de Motivos de la LORPM dice que ésta no «puede olvidar el interés propio del perjudicado o víctima del hecho cometido por el menor» y que «arbitra un amplio derecho de participación a las víctimas». Como se ve, el legislador utiliza junto al de «perjudicado» el término «víctima», mucho más próximo sin duda al de «ofendido», por lo que considero que la legitimación para participar de las facultades que ofrecía el art. 25 LORPM debía recaer sobre ambos: ofendido y perjudicado.

Delimitado quién podía personarse en el procedimiento toca pasar a examinar cuáles eran los requisitos objetivos que debían darse para que pudiera tener lugar, ya que la ley no permitía poner en marcha esta posibilidad en todo caso. Así, en primer lugar, era necesario que se tratase de hechos delictivos cometidos por mayores de dieciséis años, y, en segundo lugar, que hubieran sido cometidos «con violencia o intimidación o con grave riesgo para la vida o integridad física de las personas». Apunta la FGE, en Circular I/2000, de I8 de diciembre, que dentro del concepto «violencia» debía descartarse la vis in re o fuerza en las cosas, ya que su inclusión ampliaría las posibilidades de personación más allá de los límites razonables que imponía la ratio de la norma.

En cuanto al momento procesal en que debía realizarse la solicitud de personación, no establecía la Ley momento preclusivo alguno, disponiendo simplemente que se podía llevar a cabo «tanto en la fase instructora como en la fase de audiencia».

Las facultades que ostentaba el perjudicado personado se enumeraban en el citado art. 25, pudiendo sistematizarse del siguiente $\operatorname{modo}^{40}$ :

I) Tener vista de lo actuado, siendo notificado de las diligencias que se soliciten y acuerden.

2) Proponer pruebas y participar en su práctica, tanto en la fase de instrucción como en la de audiencia. La proposición de prueba contaba con una limitación, ya que sólo podía realizarse sobre aquellas que versaran sobre el hecho delictivo y las circunstancias de su

GANDÁSEGUI, S., «Observaciones críticas al proceso penal de la Ley Orgánica reguladora de la responsabilidad de los menores», Justicia: revista de derecho procesal, 3-4, 2004, pág. 28 (consulta online).

${ }^{38}$ Rodríguez PÉREZ, J.P., «Algunas peculiaridades...», cit., pág. I75.

${ }^{39}$ SanZ Hermida, A.M., El nuevo proceso penal del menor, cit., pág. I68.

${ }^{40}$ Miranda Estrampes, M., «Aspectos procesales de la nueva Ley reguladora de la Responsabilidad Penal del Menor (y II)», Revista Xurídica Galega, 3I, 200I, pág. 35 (disponible en: http://www.rexurga.es/; fecha de consulta: 26.V.20I4). 
comisión, quedando excluidas las relativas a la situación psicológica, educativa, familiar y social del menor.

3) Formalización del escrito de alegaciones ${ }^{4 \mathrm{~T}}$, aunque su contenido quedaba limitado a la valoración del conjunto de la prueba (sic) $)^{42}$ practicada, y a la proposición de aquellas pruebas que debían realizarse en la fase de audiencia, pero sin que pudiera proponer ninguna medida ni contener mención alguna a los hechos.

4) Asistencia a la audiencia, pudiendo durante su celebración manifestar lo que tuviera por conveniente sobre la práctica de nuevas pruebas, y, tras esta, debía oírsele en relación a los hechos probados resultantes de las mismas y a la participación del menor; pero sin que pudiera realizar manifestaciones sobre la procedencia de las medidas propuestas por el Ministerio Fiscal.

5) Interponer recurso de apelación, que únicamente podía estar fundamentado en la incompetencia del Juzgado, la inadecuación del procedimiento, el quebrantamiento de las formas esenciales del juicio que hubiera producido indefensión al perjudicado, o en la falta de apreciación de algún elemento de prueba esencial para la calificación de los hechos.

Expuestas las facultades que podía ejercitar, cabe plantearse cuál era la naturaleza de esa participación. Descartada fácilmente la posibilidad de calificar su intervención de litisconsorcial, ya que no se le permite deducir una pretensión de contenido distinto a la formulada por las partes principales, se debe entender, con la $\mathrm{FGE}^{43}$, que el perjudicado se incorpora al proceso en calidad de mero coadyuvante en el esclarecimiento de los hechos y de la participación del menor en el ejercicio de una legitimación procesal sui generis, dada su limitada capacidad de postulación y su carácter subordinado en relación con el Fiscal.

Con el contenido del original art. 25 LORPM entiendo, con PÉREZ MACHío, que se dejaba margen suficiente de actuación a los particulares perjudicados, aunque la existencia de determinadas limitaciones podía ocasionar que ciertas víctimas no viesen atendidos sus derechos: el hecho de supeditar la capacidad de intervención de la víctima a la edad del infractor, a la gravedad de las conductas y a la modalidad de la comisión del hecho ${ }^{44}$.

\section{II.5.2. La introducción de la acusación particular por la LO I5/2003}

Rompiendo con el espíritu que inspiraba la LORPM, se introduce en 2003 la posibilidad de que las víctimas se personen como acusación particular en el proceso de menores, lo que se había prohibido hasta entonces en aras de evitar cualquier intervención de carácter vindicativo. Además, pese a que con esta reforma se desvanecen los pilares básicos del Derecho Penal de menores —interés superior del menor, finalidad sancionadora-educativa y resocialización- y se cambia de rumbo respecto de lo declarado en la Exposición de Motivos del texto originario de la LORPM, la Exposición de Motivos de la LO I5/2003 no alude siquiera a esta transcendental modificación.

\footnotetext{
${ }^{4 \mathrm{r}}$ No se trataba de un escrito de alegaciones como tal, ya que no se ajustaba a lo previsto para estos en el art. 30, pero era ciertamente muy similar.

${ }^{42}$ Debe entenderse como diligencia de investigación.

${ }^{43}$ Circular FGE I/2000, de I8 de diciembre.

${ }^{44}$ PÉREZ MAChÍO, A.I., «Aproximación crítica a la intervención de la acusación particular en el proceso de menores», Eguzkilore. Cuaderno del Instituto Vasco de Criminología, 23, 2009, pág. 302 (disponible en: http://www.ehu.es/es/web/ivac/cuaderno-eguzkilore-23; fecha de consulta: 06.VI.20I4)
} 
Aunque la opción tomada por el legislador de establecer un sistema de participación de la víctima en el proceso, pero prohibiendo la acusación particular, era constitucionalmente legítima ${ }^{45}$, poco después de la entrada en vigor de la LORPM se hacía pública la intención de modificar esa participación del ofendido por el hecho delictivo, ya que el apartado I7 del Pacto de Estado para la Reforma de la Justicia de 28 de mayo de $200 \mathrm{I}$ recogía como principio el de «Fortalecer la protección y defensa de las víctimas de delitos violentos en todos los procesos penales, incluido el ámbito de la Ley Orgánica de Responsabilidad Penal del Menor». El proceso de reforma se vio acelerado por la demanda de las propias víctimas y los acontecimientos ocurridos en la época, que tuvieron gran repercusión en la opinión pública y fueron causantes de gran alarma socia ${ }^{46}$.

El fortalecimiento al que aludía el Pacto de Estado podía haberse llevado a cabo concediendo a todos los ofendidos y perjudicados la participación que otorgaba el anterior art. 25 LORPM sólo para algunos $\operatorname{casos}^{47}$; sin embargo, la nueva redacción otorgada a ese artículo por la Ley de 2003, que lo rubrica «De la acusación particular», dispone, sin reservas en cuanto al tipo de conducta delictiva o a la edad del menor imputado, que puedan personarse en el procedimiento como acusadores particulares las personas directamente ofendidas por el delito, sus padres, sus herederos o sus representantes legales si fueran menores o incapaces ${ }^{48}$.

Debe hacerse una aclaración respecto a los sujetos legitimados para el ejercicio de la acusación particular, debiendo entenderse que no pueden intervenir en el proceso todos los mencionados por el precepto simultáneamente y en las mismas condiciones. Cuando el ofendido por el hecho delictivo goce de capacidad para ser parte y de capacidad procesal, sólo él podrá ejercer la acción penal en calidad de acusador particular. En caso de fallecimiento, el finado pierde la capacidad para ser parte y la ley legítima a sus herederos para el ejercicio de la acción. En situaciones de ausencia de capacidad de obrar del ofendido - por incapacitación o por minoría de edad-, la correlativa falta de capacidad procesal deberá remediarse con la intervención del representante legal — sean sus padres o un tutor-, pero la condición de parte, con todas sus facultades y cargas, corresponde exclusivamente al menor o incapacitado, y no al padre o al tutor, como parece dar a entender la Ley ${ }^{49}$.

En cuanto a la forma de constitución en parte encontramos opiniones contrapuestas: así, mientras que para REVERÓN PALENZUELA debería llevarse a cabo bien

${ }^{45}$ El TC ha afirmado categóricamente que el ejercicio de la acción penal por parte de la acusación particular es un derecho de configuración legal y, por tanto, el legislador es libre de no incorporar dichas figuras en el proceso penal dado que el ejercicio del ius puniendi es de titularidad estatal y no privada (SSTC II5/200I, de IO de mayo; y I79/2004, de I8 de octubre).

${ }^{46}$ Especialmente el caso de Sandra Palo, en el que tres menores violaron, atropellaron y prendieron fuego a una disminuida psíquica, en el que se dictó sentencia en octubre de 2003. Con el acto del juicio se produjo un clamor popular en el sentido de dar mayor participación a las víctimas, reflejado ampliamente por los medios de comunicación. El Ministro de Justicia anunció una reforma de la Ley del menor, lo que se produjo en noviembre del mismo año. Vid. Mingo BASAíl, M.L., «Posición de las víctimas en el proceso penal de menores. De la prohibición a la aceptación de la acusación particular», Diario La Ley, 6099, 2004, pág. I3 (consulta online).

${ }^{47}$ Ibíd.

${ }^{48}$ García-Rostán Calvín, G., El Proceso Penal de Menores: Funciones del Ministerio Fiscal y del Juez en la instrucción, el período intermedio y las medidas cautelares, $\mathrm{I}^{\mathrm{a}}$ edición, Cizur Menor (Navarra), Thomson-Aranzadi, 2007, pág. 69.

${ }^{49}$ Ibíd., pág. 7I. 
mediante la interposición de denuncia, bien esperando a la incoación del expediente y el oportuno ofrecimiento de acciones por el Ministerio Fiscal, ya que entiende vedada la posibilidad de interponer querella por la ausencia de juez de instrucción competente (art. 272 LECrim) ${ }^{5 \circ}$; para GARCíA-ROSTAN CALVín el acto para adquirir la condición de parte en el proceso penal de menores es la querella, debiendo ser el Juez de Menores quien resuelva acerca de su admisión a trámite (art. 25 LORPM, último párrafo) $)^{51}$.

La reforma operada en el art. 25 no ha variado su estructura, pues sigue manteniendo un listado de facultades de actuación procesal, sin carácter tasado, que se confieren a la víctima, pese a que su condición de parte hace superflua tal información, siendo preferible que se hubiera limitado a reconocer la condición de acusador particular y a disponer las limitaciones a las que se ve sometido como consecuencia de la especial condición del sujeto imputado ${ }^{52}$.

Dos son las novedades destacables que se introducen en cuanto a los actos procesales autorizados a la víctima: instar la imposición de medidas y ser oído en caso de modificación o de sustitución de éstas. El resto de facultades que aparecen en ese listado - tener vista de lo actuado, proponer prueba y participar en su práctica, interponer recursos, etc.- ya se recogían en el régimen anterior.

El derecho a instar la imposición de medidas se encuentra con un problema, y es que el art. 25.d) LORPM, en sede de propuesta de pruebas, manifiesta específicamente la imposibilidad de que las mismas versen sobre aspectos personales, familiares, educativos, sociales o psicológicos del menor, lo que se ha interpretado por la doctrina como el veto al informe del Equipo Técnico, al que por respeto al derecho de la intimidad del menor sólo tendrán acceso el Ministerio Fiscal y el Juez de Menores ${ }^{53}$. Pues bien, si la medida aplicable debe regirse por el principio del interés superior del menor, ajustándose a las circunstancias personales del mismo, si se desconoce dicha situación individual por la acusación particular, difícilmente la medida que proponga podrá conciliar con los objetivos perseguidos por la normativa de menores, centrándose entonces en motivos puramente retributivos, punitivos y vindicativos.

Frente a esto, hay autores que consideran que lo anterior no es perjudicial para los intereses del menor «si se tiene en cuenta que la decisión final sobre la medida a imponer al delincuente únicamente corresponde al juez, el cual, revestido de la imparcialidad que le exige la Constitución, ha de establecer la que sea justa atendidos todos los elementos condicionantes» ${ }^{54}$. Ante este planteamiento, es fácil advertir, con PÉREZ MACHÍo, que, teniendo el Juez de Menores la facultad de rechazar las propuestas de las víctimas cuando resulten manifiestamente contrarias al interés del menor, la eficacia de la participación de

\footnotetext{
${ }^{50}$ Reverón Palenzuela, B., «La acusación particular en el proceso penal de menores» en AA.VV., Derecho penal y psicología del menor, $\mathrm{I}^{\mathrm{a}}$ edición, Granada, Comares, 2007, págs. 253.

${ }^{51}$ García-Rostán Calvín, G., El Proceso Penal de Menores..., cit., pág. 74.

${ }^{52}$ Ibíd., pág. 7I.

${ }^{53}$ PÉREZ MACHÍO, A.I., «Aproximación crítica...», cit., pág. 306.

${ }^{54}$ García-Rostán Calvín, G., El Proceso Penal de Menores..., cit., pág. 69. Igualmente Mingo Basaíl entiende que la petición de medidas por la acusación particular no debe tener necesariamente en cuenta el interés del menor, dada su posición procesal; no resultando inconveniente puesto que será el Juez de Menores quien decida finalmente sobre la medida a imponer, y éste si está obligado a tener en cuenta el interés del menor; en «Posición de las víctimas...», cit., pág. I5 (consulta online).
} 
los perjudicados parece reducirse a los supuestos en los que existe una armonía entre las pretensiones de la Fiscalía y las procedentes de la acusación particular, reduciéndose en caso contrario a un mero reconocimiento jurídico («derecho al pataleo») pero sin ningún tipo de influencia procesal ${ }^{55}$.

La segunda novedad importante consiste en el derecho de las víctimas a ser oídas en caso de modificación o de sustitución de las medidas impuestas al menor (art. 25.g) LORPM). La LORPM permite al Juez de Menores gran flexibilidad en cuanto a las posibilidades de modificar, reducir, sustituir o dejar sin efecto la medida impuesta (arts. I3 y 5I), para lo que, hasta la reforma de 2003, debía oír al Ministerio Fiscal, al letrado del menor, al Equipo Técnico y, en su caso, a la entidad pública encargada de la ejecución. Igualmente, debe analizarse el expediente personal del menor, en el que se archivan todos los procedimientos que se hubieran tramitado contra él (art. 20.2 LORPM), y que contiene, no sólo cuestiones fácticas de las específicas infracciones ilícitas, sino también datos relativos a la situación personal, familiar y psicológica del menor. Por tanto, y al igual que sucedía con la proposición de medida, la acusación particular no tendrá acceso a esta información, y su intervención, una vez más, parece estar sólo motivada por razones de carácter vindicativo y retributivo, tropezando la facultad concedida en el art. 25.g) LORPM con la finalidad y los objetivos que debe perseguir la normativa de menores ${ }^{56}$. Con GómEz RECIO entendemos que hubiera sido más honesto prescindir de la intervención de la acusación particular en ejecución de sentencia, como, hasta ahora ha venido ocurriendo en la jurisdicción de adultos ${ }^{57}$, donde no se oye al perjudicado sobre la concesión al condenado del tercer grado penitenciario o sobre el adelantamiento de su libertad condicional ${ }^{58}$.

Finalmente, la LO 8/2006 también introdujo novedades respecto de las víctimas. Además de desarrollar la participación de la acusación particular que tan atropelladamente se había introducido en 2003 , incorpora un precepto dedicado íntegramente a los «derechos de las víctimas y los perjudicados» (art. 4 LORPM).

La propuesta de otorgar un mayor reconocimiento y protección a las víctimas arranca de instrumentos supranacionales, con la Decisión Marco del Consejo de I5 de marzo de 200I relativa al Estatuto de la víctima en el proceso penal ${ }^{59}$, lo que se plasmó, en nuestro Derecho interno, en la Instrucción de la FGE 8/2005, de 26 de julio, sobre el deber de información en la tutela y protección de las víctimas en el proceso penal ${ }^{60}$.

La nueva redacción del art. 4 LORPM, en la línea de esa preocupación, reitera en parte lo ya dispuesto en el art. 25, pero también colma alguna de las lagunas que éste había

${ }^{55}$ Pérez Machío, A.I., «Aproximación crítica...», cit., pág. 306.

${ }^{56}$ Ibíd., pág. 307.

${ }^{57}$ Sin embargo, el Anteproyecto de Ley Orgánica del Estatuto de la víctima del delito, que se elabora mientras se realiza este trabajo, si incorpora determinadas facultades de participación de las víctimas en ejecución, como la posibilidad de recurrir determinados autos del Juez de Vigilancia Penitenciaria o interesar que se impongan al liberado condicional las medidas que consideren necesarias para garantizar su seguridad.

58 Gómez Recio, F., «La introducción en la LORPM del acusador particular» (disponible en: http://noticias.juridicas.com/articulos/65-Derecho-Procesal-Penal/200409-5476I4I9III0353777.html; fecha de consulta: I2.VI.20I4).

${ }^{59}$ DOUE $n^{\circ} \mathrm{L} 082$ de 22 de marzo de $200 \mathrm{I}$.

${ }^{60}$ Y que cristalizará, finalmente, en la Ley Orgánica del Estatuto de la víctima del delito, cuyo anteproyecto hemos citado supra. 
generado; como el derecho a que se comunique a las víctimas y perjudicados todas aquellas resoluciones que, adoptadas tanto por el Ministerio Fiscal como por el Juez de Menores, puedan afectar a sus intereses, en especial la sentencia; y regula, adicionalmente, los derechos que asisten a las víctimas que deciden no hacer uso del derecho de acusar.

\section{El régimen especial de la responsabilidad civil}

La LTTM excluía de la competencia de estos Tribunales el conocimiento de la responsabilidad civil, lo que obligaba al perjudicado a acudir «ante los Tribunales ordinarios del orden civil en la clase de juicio que proceda» (art. I4), manteniéndose esta regulación tras la LORCPJM.

Frente a ello, la LORPM (art. 2.2) optó por atribuir a los Juzgados de Menores competencia para conocer y resolver sobre las responsabilidades civiles derivadas de los hechos cometidos por los menores que caen dentro de su ámbito de aplicación, estableciendo una regulación «en cierto modo revolucionaria» ${ }^{6 \mathrm{I}}$, tanto desde el punto de vista material, porque amplía el tipo de responsabilidad civil prevista en el CP —basado en culpa o negligencia-, convirtiendo en objetiva y solidaria la de los «padres, tutores, acogedores y guardadores»; como desde el punto de vista procesal, porque se aparta del criterio anterior de la legislación tutelar ${ }^{62}$.

Su Título VIII (arts. 6I a 64) reguló inicialmente un proceso autónomo especial y sumario para la determinación de la responsabilidad civil ex delicto ${ }^{63}$, que, tras la reforma de 2006, vio alterado todo su tratamiento procesal; por lo que intentaremos exponer aquí las características de uno y otro régimen.

Con la introducción de esta nueva regulación se habla de un tertium genus de responsabilidad aquiliana, que se suma a las previstas en el CC y en el CP, configurando así un triple régimen de responsabilidad civil, al que se podría sumar un cuarto, dado que la Ley 30/1992, de 26 de noviembre, de Régimen Jurídico de las Administraciones Públicas y del Procedimiento Administrativo Común (en adelante LRJAP-PAC) también contiene normas sobre la responsabilidad de las Administraciones ${ }^{64}$.

\section{III.I. Competencia}

El órgano judicial competente para conocer de la pieza de responsabilidad civil es, como hemos dicho, el mismo que conoce de la pieza principal, esto es, el Juzgado de Menores o el Juzgado Central de Menores de la Audiencia Nacional. Aunque esto suscitó dudas de constitucionalidad, fueron desechadas por el ATC 275/2005, de 22 de junio, al aclarar que el hecho de que estos Juzgados conozcan de la pretensión civil perteneciendo al orden penal «no vulnera ni el principio de exclusividad jurisdiccional (art. II7.3 CE), ni los derechos a la tutela judicial efectiva sin indefensión y al proceso con todas las garantías (art.

\footnotetext{
${ }^{6 r}$ Exposición de Motivos LORPM, apartado 8.

${ }^{62}$ Morenilla Allard, P., El proceso penal del menor..., cit., pág. I9I.

${ }^{63}$ SAnZ Hermida, A.M., El nuevo proceso penal del menor, cit., pág. 3I4.

${ }^{64}$ DÁvila GonZÁleZ, J., «La responsabilidad civil en la Ley Orgánica 5/2000, de responsabilidad penal de los menores», en Llamas Pомво, E. (Coord.), Estudios de derecho de obligaciones: homenaje al profesor Mariano Alonso Pérez, I edición, Madrid, La Ley, 2006, pág. 3 (consulta online).
} 
24.I y 2 CE), pues, de dichos preceptos no deriva un contenido competencial indisponible entre jurisdicciones de distintos órdenes, ni la imposibilidad de que un órgano judicial penal conozca de la responsabilidad civil derivada de la comisión de un ilícito penal. Por el contrario, es tradicional en nuestro sistema jurisdiccional que los órganos judiciales integrados en la Jurisdicción penal conozcan de la responsabilidad civil derivada del ilícito penal cometido por adultos, incluso aunque — por ausencia de culpabilidad - no se declare la responsabilidad penal» $\left(\mathrm{FJ} 5^{\circ}\right)$.

Por otro lado, los Juzgados de Menores no serán competentes para conocer de los procedimientos de responsabilidad civil por los daños ocasionados por un ilícito de un menor de catorce años, sino que deberá dilucidarse ante los órganos jurisdiccionales civiles, conforme a la regulación establecida en el CC y en la LEC. También será necesario acudir al orden civil cuando en la causa principal haya recaído sentencia absolutoria o se haya procedido al sobreseimiento libre por inexistencia del hecho o porque se estime que el menor no lo cometió ${ }^{65}, \mathrm{y}$, obviamente, cuando el perjudicado se reserve la acción civil (art. 6I.I LORPM).

Mayores problemas pueden conllevar, por la oscuridad de su regulación, las acciones tendentes a exigir la responsabilidad de la Administración derivada de los actos de los menores a su cargo. El art. 6I.4 LORPM establece que, en su caso, se aplicará también lo dispuesto en el art. I45 LRJAP-PAC, lo que podría llevar al error de considerar que, en estos casos, se atribuye directamente la competencia al orden contencioso administrativo. Pero lo cierto es que los Juzgados de Menores son competentes para conocer de las demandas dirigidas contra una Administración Pública, ex art. 6I.3 LORPM, cuando sea tutora, acogedora o guardadora del menor ${ }^{66}$; y sólo en los casos en que se sustrae la competencia de estos Juzgados para conocer de la pieza de la responsabilidad civil — menores de catorce años, sentencia absolutoria, sobreseimiento libre-, se seguirá el procedimiento para reclamar la responsabilidad patrimonial de la Administración originada por el funcionamiento normal o anormal de sus servicios.

\footnotetext{
${ }^{65}$ SAnZ Hermida, A.M., El nuevo proceso penal del menor, cit., pág. $3 \mathrm{I} 7$.

${ }^{66}$ En este sentido se ha pronunciado la jurisprudencia menor. Así, la SAP Valladolid, Sección $2^{\text {a }}$, de 22 de diciembre de 2002, entiende que «la Jurisdicción de Menores, con el alcance y contenido prevenidos en los artículos 6r a 64 de la Ley Orgánica 5/2000, es hábil y adecuada para resolver la reclamación civil de los daños y perjuicios derivados de infracciones penales cometidas por menores, y ello porque, si bien es cierto que el apartado 4 del artículo 6i de dicha Ley establece que, en su caso, se aplicará también lo dispuesto en el artículo I45 de la Ley 30/92, de 26 de noviembre, de Régimen Jurídico de las Administraciones Públicas y del Procedimiento Administrativo Común, no lo es menos que tal disposición ha de ponerse en relación con el número anterior del indicado artículo 6r y en el sentido de que cabe deducir la responsabilidad civil contra la Administración Pública por este procedimiento ante el Juzgado de Menores cuando la misma se encuentre en alguna de las situaciones legales mencionadas (tutor, acogedor o guardador legal o de hecho del menor que ha cometido el ilícito penal causando los daños o perjuicios), no pudiendo confundir o identificar esta responsabilidad con la responsabilidad patrimonial de la Administración puesto que aquella presenta un origen ex delicto y se extiende a las personas indicadas en el citado artículo 6r.3 en función del deber de control y vigilancia que los padres tutores o guardadores han de tener sobre los menores a su cargo en virtud de la relación de filiación o de los mecanismos de protección jurídica del menor previstos legalmente» $\left(\mathrm{FJ} \mathrm{I}^{\circ}\right)$. Igualmente, la SAP Tarragona, Sección $2^{\mathrm{a}}$, de I2 de abril de 2005, establece que «los guardadores legales o de hecho del menor, sean públicos o privados, responden solidariamente con él y la jurisdicción competente es la de menores» $\left(\mathrm{FJ} 3^{\circ}\right)$.
} 


\section{III.2. Legitimación}

III.2.I. Activa

La legitimación activa corresponde al perjudicado por el acto punible cometido por el menor y, sólo subsidiariamente, en sustitución de aquél, al Ministerio Fiscal, pese a que del tenor literal del art. 6I.I LORPM puede parecer que se establezca lo contrario ${ }^{67}$.

Así, la LORPM adopta en este punto un criterio radicalmente opuesto al que rige en los procesos penales de adultos, donde el Fiscal ejercita conjuntamente las acciones penales y civiles derivadas del hecho delictivo, con independencia de que el perjudicado la ejercite por sí mismo o no y con la única limitación de la renuncia expresa o reserva de la acción civil que tal perjudicado pueda entablar ${ }^{68}$.

De esta manera, existen tres supuestos en los que el Ministerio Fiscal no puede ejercitar la acción civil:

$\left.I^{\circ}\right)$ Cuando el perjudicado renuncie al ejercicio de la acción. Aunque la LORPM no lo exija, parece razonable entender que esa renuncia ha de ser expresa, tal y como se prevé en el art. II2 LECrim $^{69}$. En cuanto al momento en que puede plantearse resulta de aplicación lo dispuesto en la LEC, que admite la posibilidad de que pueda formularse en cualquier momento, antes del inicio o durante la tramitación del procedimiento.

$2^{\circ}$ ) Cuando el perjudicado la ejercite por sí mismo en el plazo de un mes desde que se le notifique la apertura de la pieza de responsabilidad civil. Ahora bien, transcurrido dicho plazo sin que el perjudicado se haya personado, la legitimación subordinada del Ministerio Fiscal recobra su plenitud, debiendo ejercitar con carácter obligatorio la acción civil, salvo que el perjudicado haya renunciado o se haya reservado la misma ${ }^{70}$.

Cabe advertir, con GARCIANDÍA GonZÁlEZ, que este plazo de un mes sirve únicamente a los efectos de personación en el proceso de menores, sin suponer cortapisa temporal alguna a la posibilidad de formular la pretensión del perjudicado en la vía civil ordinaria $^{7 \mathrm{I}}$.

Si con posterioridad a ese plazo el perjudicado ejercitara la acción en el orden civil o llegara a un acuerdo de reparación, resarcimiento o indemnización con los responsables civiles, el Ministerio Fiscal, aun cuando estuviera ejercitando la acción civil ante el Juzgado de Menores, deberá cesar en dicha actuación ${ }^{72}$.

$\left.3^{\circ}\right)$ Cuando el perjudicado se reserve la acción civil para ejercitarla ante el orden jurisdiccional común, no siendo en este caso aplicables las normas de la LORPM, sino las contenidas en el CC (arts. I902 y ss.) y en la LEC.

\footnotetext{
${ }^{67}$ Garciandía González, P.M., «Tratamiento procesal de la responsabilidad civil en el proceso penal de menores tras la reforma de 2006: reflexiones a la luz de la Circular de la Fiscalía General del Estado I/2007, de 26 de noviembre», REDUR, 5, 2007, pág. 28 (disponible en: http://www.unirioja.es/dptos/dd/redur/numero5.htm; fecha de consulta: 26.V.20I4).

${ }^{68}$ DíAz MARTínez, M., «El régimen especial de la responsabilidad civil en el proceso penal de menores», Diario La Ley, 6515, 2006, pág. 4 (consulta online).

${ }^{69}$ Ibíd.

${ }^{70}$ Vid. SAP Jaén, Sección I ${ }^{\mathrm{a}}$, de 28 de noviembre de 2002.

${ }^{71}$ GarCiandía GonZÁlez, P.M., «Tratamiento procesal...», cit., pág. 29.

${ }^{72}$ SAnz HermidA, A.M., El nuevo proceso penal del menor, cit., pág. 3I9.
} 
Finalmente, junto al Ministerio Fiscal y al perjudicado que haya sido notificado de la apertura de la pieza de responsabilidad civil, también podrán personarse quienes espontáneamente se consideren perjudicados y las compañías aseguradoras que se tengan por interesadas (art. 64.2 $2^{a}$ LORPM), esto es, las aseguradoras en aquellos casos en que se subroguen en la situación del perjudicado, en virtud de la indemnización abonada a éste.

Para estos sujetos la Ley no prevé plazo de personación, a diferencia de lo que sucede con los perjudicados a los que se dirige la notificación -que, como sabemos, disponen de un plazo de un mes desde la misma-. De admitir que dicho plazo les es aplicable quedaría sin resolver cuál es el dies a quo para su cómputo, dado que no reciben notificación alguna; por lo que resulta más conveniente entender, con DíAz MARTíNEZ, que podrán personarse en cualquier momento hasta la fase de audiencia, transcurrida la cual sólo les quedaría el derecho de acudir a la vía civil ordinaria ${ }^{73}$.

\section{III.2.2. Pasiva}

El art. 6I.3 LORPM establece que «cuando el responsable de los hechos cometidos sea un menor de dieciocho años, responderán solidariamente con él de los daños y perjuicios causados sus padres, tutores, acogedores y guardadores legales o de hecho, por este orden».

De conformidad con ello, el primer legitimado pasivamente es el menor responsable del hecho delictivo. No existe en la Ley ninguna solución prevista para los supuestos en que varios menores hayan participado en los hechos delictivos de los que se derivan los daños, laguna legal que ha de colmarse acudiendo supletoriamente a lo dispuesto en el art. Iı6.2 CP, que establece la regla de la solidaridad para los distintos autores entre $\mathrm{si}^{14}$.

Junto a la del menor, concurre la responsabilidad civil de los implicados en su guarda y custodia - padres, tutores, acogedores y guardadores-; con la novedad, como dijimos, de establecerse una responsabilidad objetiva, ampliando así el tipo de responsabilidad ex delicto del CP, basada en la culpa o negligencia de aquéllos.

Aunque el menor imputado es el principal responsable, eso no excluye o exonera a los responsables solidarios, y ello ni aun cuando acrediten haber actuado con la máxima diligencia. Únicamente podrá el Juez de Menores moderar esa responsabilidad en casos de que no hayan favorecido la conducta infractora del menor con dolo o negligencia grave.

Como ha puesto de manifiesto la jurisprudencia menor, la intención del legislador al establecer este sistema de responsabilidad civil de mayor alcance que el previsto en el CC responde a una doble finalidad: de un lado, amparar mejor los derechos de las víctimas al libelarles de tener que probar la culpa del responsable civil, protegiéndolas también frente a la común insolvencia del menor infractor, asegurándoles así, mediante un sistema objetivo, sin fisuras ni excusas, la indemnización de los daños sufridos por tales víctimas; y, de otro, conseguir una mayor implicación de los padres en el proceso de socialización de los

\footnotetext{
${ }^{73}$ DíAz MARTíneZ, M., «El régimen especial...», cit., pág. 7 (consulta online).

${ }^{74}$ Ibíd., pág. 8.
} 
menores, imponiéndoles las consecuencias civiles de las infracciones que éstos cometan por la transgresión del conjunto de deberes que tienen sobre ellos ${ }^{75}$.

En cuanto al alcance que debe darse a la expresión «por este orden», que acompaña a la relación de personas que responden solidariamente con el menor, la interpretación que se ha visto avalada por la mayor parte de las resoluciones de nuestras Audiencias Provinciales $^{76}$, es la tesis de la gestión efectiva del proceso educativo. Esta consiste en interpretar el orden establecido por el legislador de forma flexible, con criterio lógico y no excluyente, debiendo responder los obligados solidarios que en el momento de producirse los hechos se hallaban gestionando efectivamente el proceso educativo del menor, y ello con independencia de que existan sujetos que preceden en el orden literal contenido en la norma ${ }^{77}$.

Para los menores emancipados, entiende DÁVILA GONZÁLEZ que no ha de aplicarse el art. 6I.3 LORPM, y no debe haber nadie que responda solidariamente, ya que la emancipación supone la extinción de la patria potestad y no puede hablarse de acogimiento ni de guarda de un menor emancipado. Eso sí, para que sea efectiva de cara a la liberación de responsabilidad de los padres, la emancipación debe ser inscrita en el Registro Civil, ya que de lo contrario no producirá efectos contra terceros (art. 3I8 CC), debiendo ser considerados como tales los perjudicados ${ }^{78}$.

Por otro lado, el art. 6I.3 LORPM no incluye a los titulares de centros escolares en la enumeración de los sujetos responsables solidarios, lo que llevaría a la no inclusión de éstos en su ámbito de aplicación. Sin embargo, existen sentencias que admiten la condena solidaria de los padres y del centro docente considerándoles guardadores de hecho ${ }^{79}$, mientras otras señalan la posibilidad de exigir a los centros docentes, públicos y privados, al amparo de los arts. І20 у г2 г CP, responsabilidad civil subsidiaria por los actos ilícitos cometidos por los alumnos menores de edad ${ }^{80}$.

Están también pasivamente legitimados las aseguradoras que hubiesen asumido el riesgo de las responsabilidades pecuniarias derivadas de los actos de los menores, en tanto que responsables civiles directos hasta el límite de la indemnización legalmente establecida o convencionalmente pactada (art. 63 LORPM).

${ }^{75}$ SAP Badajoz, Sección $3^{\mathrm{a}}$, de 25 de enero de 2005 (FJ $3^{\circ}$ ); con referencia a otras de Cantabria de 23 de diciembre de 2003 , Jaén de Io de enero de 2003 y de 28 de noviembre de 2002 , y Burgos de i2 de abril y de 30 de diciembre de 2002 .

${ }^{76}$ SSAP Valladolid, Sección $2^{\text {a }}$, de 22 de noviembre de 2002; Jaén, Sección I ${ }^{a}$, de I8 de enero de 2005; La Rioja, Sección I ${ }^{\mathrm{a}}$, de 3 de octubre de 2005; y Cuenca, Sección I ${ }^{\mathrm{a}}$, de 2 de noviembre de 2005.

${ }^{77}$ Garciandía GonZÁlez, P.M., «Tratamiento procesal...», cit., pág. 32.

${ }^{78}$ DÁvila GonZÁlez, J., «La responsabilidad civil...», cit., pág. 6 (consulta online). En el mismo sentido, VAquer Aloy, A., «La responsabilidad civil», en Gómez Colomer, J.L. (Coord.), Justicia penal de menores $Y$ jóvenes: (análisis sustantivo y procesal de la nueva regulación), Iª edición, Valencia, Tirant lo Blanch, 2002, pág. I39.

${ }^{79}$ Así, la SAP Cantabria, Sección $4^{a}$, de 23 de diciembre de 2003 , entiende que «el centro de enseñanza se va a equiparar a guardador de hecho (entendiendo por tal, en sentido amplio, aquella persona que, por propia iniciativa o por acuerdo con los padres o tutores, ejercita funciones de guarda, de forma continuada e independiente), ya que asumen por delegación las funciones de vigilancia y guarda de los menores desde su entrada en el centro hasta la salida del mismo, durante la jornada lectiva de forma regular durante todo el año escolar (sin olvidar, lógicamente, el relevante papel que desempeña en la formación y educación del menor)» (FJ $\left.5^{\circ}\right)$.

${ }^{80}$ SAP Álava, Sección I ${ }^{a}$, de 27 de mayo de 2005. 
Por último, el art. 6r.4 LORPM establece, como sabemos, la aplicación, en su caso, del art. I45 LRJAP-PAC. Como ya adelantamos, consideramos que la Administración que ejerza la guarda del menor infractor tiene legitimación pasiva como responsable civil directa y solidaria (art. 6I.3 LORPM) ${ }^{8 \mathrm{r}}$, y el art. I45 LRJAP-PAC sólo será de aplicación cuando la fuente de la obligación no fuera el acto ilícito penal ${ }^{82}$.

\section{III.3. Postulación}

El art. 64.II ${ }^{a}$ LORPM, en su redacción original, eximía del presupuesto de la postulación procesal de los actores, permitiéndose que el responsable civil directo pudiera reclamar un abogado de oficio, así como la posibilidad de que los representantes legales del menor —debiendo entender por tales las personas enumeradas en el art. 6I.3 LORPMfuesen defendidos por el letrado designado al menor en el procedimiento principal, si así se aceptaba por aquél.

Tras la reforma de 2006 nada se dice en el art. 64 LORPM sobre la capacidad de postulación, si bien su art. 4 se remite a la LECrim, al tiempo que recuerda el derecho del perjudicado de solicitar el beneficio de la justicia gratuita si carece de medios económicos e instar el nombramiento de Abogado de oficio. En todo caso, al ser materia civil, deben regir supletoriamente las reglas comunes sobre postulación de la $\mathrm{LEC}^{83}$. De acuerdo con ellas, la capacidad de postulación será facultativa si la cuantía de la pretensión es inferior a los 2.000 euros y obligatoria si fuera igual o superior a dicha cantidad (arts. 23.2.I ${ }^{\mathrm{a}}$ y 3I.2. $\mathrm{I}^{\mathrm{a}}$ LEC).

No obstante, frente a la obligatoria defensa por letrado, la Circular FGE I/2007 entiende que no será necesario actuar a través de Procurador, ya que, si en el proceso de menores ni el menor infractor ni la acusación particular lo necesitan, «con más razón habrá de exonerar de tal requisito a quien exclusivamente actúe como actor civil o como responsable civil» (apartado VIII.3).

\section{III.4. Procedimiento}

La reforma operada por la LO 8/2006 fue radical en cuanto al tratamiento procesal de la pretensión civil en el proceso penal de menores, suprimiendo el proceso civil sumario inicialmente previsto y sustituyéndose por unas pocas especialidades similares a lo dispuesto en la ley procesal penal de adultos con relación a esta materia. Por ello, pasaremos brevemente por las características del procedimiento originario para, a continuación, centrarnos en el proceso actualmente vigente.

\section{III.4.I. El procedimiento instaurado por la LORPM}

Iniciación.- Notificado el Decreto de incoación del expediente del Ministerio Fiscal al Juez de Menores, éste abre la pieza separada de responsabilidad civil, y notifica al perjudicado su derecho a ser parte en la misma (arts. I6.4 y 64.I ${ }^{\mathrm{a}}$ LORPM). Asimismo, el Juez de Menores notifica al menor y a sus representantes legales, en su caso, su condición de posibles responsables civiles (art. 64.3 $3^{\mathrm{a}}$ LORPM).

\footnotetext{
${ }^{8 \mathrm{r}} \mathrm{A}$ diferencia del régimen del art. I2I CP, que establece la responsabilidad subsidiaria de la Administración.

${ }^{82}$ MoRenilla Allard, P., El proceso penal del menor..., cit., pág. 202.

${ }^{83}$ Ibíd., pág. 207.
} 
Una vez personadas las partes, el Juez de Menores mediante auto acuerda el inicio del procedimiento, señalando quiénes son actores y quiénes son demandados, y concede a los primeros un plazo de diez días para que presenten un escrito en el que hagan constar sus alegaciones y las pruebas de que intenten valerse (art. 64.4 ${ }^{a}$ LORPM).

Por otro lado, consecuente con el principio de unidad de expediente (art. 20.I LORPM), dispone el art. 6I.2 LORPM que por cada uno de los hechos imputados se tramitará una pieza separada de responsabilidad civil; lo que debe entenderse con independencia tanto del número de perjudicados como de partícipes en la infracción penal. En cambio, en todos aquellos casos en que existan varios hechos delictivos conexos, según propone la Fiscalía, deberá abrirse una sola pieza comprensiva de la responsabilidad civil derivada de todos ellos ${ }^{84}$.

Alegaciones.- Dispone el art. $64.4^{\mathrm{a}}$ LORPM que en el escrito de las partes demandantes harán constar sus pretensiones así como la prueba que consideren necesaria, incluida la confesión en juicio y la de testigos. Aunque no se dice expresamente, se ha considerado que se trata de un escrito de demanda, por lo que deberá respetar los requisitos establecidos en el art. 399 LEC $^{85}$.

A continuación, el Juez de Menores da traslado del escrito a los demandados, para que contesten y puedan a su vez proponer la prueba que estimen oportuna (64.5 ${ }^{\mathrm{a}}$ LORPM), debiendo seguir los requisitos establecidos al efecto en el art. 405 LEC.

La LORPM no prevé expresamente la posibilidad de que el demandado deje precluir el plazo sin contestar a la demanda, debiendo estar a lo dispuesto en el art. 4I4 LEC.

Vista oral.- Con ambos escritos en poder del Juez, éste convoca a las partes a una vista oral en la que, por su orden, deberán realizar las alegaciones correspondientes y se practicará la prueba admitida, sin que pueda rechazarse la prueba de confesión ni la testifical por el hecho de haberse ya practicado en el expediente principal (art. 64.6 ${ }^{\mathrm{a}}$ LORPM). En este sentido, los medios de prueba de que podrán valerse las partes deberán ser los previstos en el art. 299 LEC, por lo que la denominada «confesión en juicio» en la LORPM se refiere al «interrogatorio de las partes». La naturaleza civil de esta causa justifica igualmente el empleo de los criterios recogidos en la LEC para la valoración de la prueba.

Además, puede unirse a los autos testimonio de lo actuado en el expediente principal que el Juez considere relevante para su decisión (art. 64.7 LORPM).

Sentencia, recurso y ejecución.- Establece el art. 64.8 $8^{\mathrm{a}}$ LRPM que la sentencia que resuelva la pieza separada de responsabilidad civil se dictará una vez terminado mediante resolución definitiva el procedimiento de menores. De lo anterior deriva que el Juez de Menores debe resolver sobre la responsabilidad civil pese a que no llegue a fallar sobre la

\footnotetext{
${ }^{84}$ Circular FGE I/2000, de I8 de diciembre (apartado XII.I).

${ }^{85}$ SAnz Hermida, A.M., El nuevo proceso penal del menor, cit., pág. 329. Para Cuesta Merino, el carácter «poco formalista» y la posibilidad de intervención del perjudicado sin asistencia técnica permiten concluir que la demanda puede presentarse de forma «sucinta», tal como se recoge en el art. 437 LEC para el Juicio Verbal, y que posteriormente sea completada al comienzo de la vista mediante la exposición por demandantes y demandados de «sus pretensiones y sus alegaciones sobre todo aquello que consideren relevante al objeto del proceso» (art. 64.6 $6^{\mathrm{a}}$ LORPM); «La responsabilidad civil en el nuevo proceso penal de menores», en GómEZ Colomer, J.L. (Coord.), Justicia penal de menores y jóvenes: (análisis sustantivo y procesal de la nueva regulación), $\mathrm{I}^{\mathrm{a}}$ edición, Valencia, Tirant lo Blanch, 2002, pág. 337.
} 
responsabilidad criminal del menor ${ }^{86}$ y que, aunque hasta el momento de la vista oral la tramitación de la pieza principal y la de responsabilidad civil hayan coincidido en el tiempo, la decisión que deba recaer en ésta deberá suspenderse hasta que exista resolución definitiva en aquélla, dada la naturaleza prejudicial de la misma.

La sentencia declarará la responsabilidad o absolverá a los demandados, debiendo en el primer caso establecer las bases en que se fundamenta la cuantía de los daños e indemnizaciones, pudiendo fijarse en la propia resolución o en el momento de su ejecución (art. II5 CP, por remisión del art. 64.8 $8^{\mathrm{a}}$ LORPM).

La sentencia podrá ser objeto de recurso de apelación ante la Audiencia Provincial ${ }^{87}$, sustanciándose por los trámites de la LEC que por la cuantía corresponda. Una vez firme, podrá ser ejecutada de acuerdo con las normas del CP y de la LEC (art. 64.9ª).

Quizá uno de los aspectos que más críticas ha suscitado es el no reconocimiento a la sentencia civil de fuerza de cosa juzgada (art. 64.10 ${ }^{a}$ LORPM), pudiendo las partes promover juicio ordinario sobre la misma cuestión. La única limitación radica en que en el posterior declarativo «se consideran hechos probados los hechos que el Juez de Menores haya estimado acreditados, así como la participación del menor»; siendo el único efecto de esta sentencia, por tanto, el prejudicial ${ }^{88}$.

Este precepto plantea numerosos interrogantes. En primer lugar, el proceso declarativo posterior podrá plantearse tanto en caso de sentencia condenatoria como absolutoria. La sentencia condenatoria, una vez firme, podrá ejecutarse, con lo que cabe la posibilidad de que mientras se ejecuta ésta se plantee un procedimiento que enjuicie los mismos hechos ya debatidos. El Juez ordinario, claro está, deberá tener en cuenta el fallo de la sentencia dictada por el Juez de Menores, a fin de evitar el enriquecimiento injusto de la víctima. En caso de sentencia absolutoria, la responsabilidad civil sólo podrá fundamentarse en los arts. 1902 y siguientes CC, pues ya no se tratará de responsabilidad civil ex delicto ${ }^{89}$.

En segundo lugar, no se establece ningún plazo de prescripción, por lo que parece que debe someterse al general de quince años, tal y como lo ha venido considerando la jurisprudencia para la responsabilidad civil derivada de delito.

Finalmente, resulta también dudoso el alcance de la expresión «hechos probados», pues la duplicidad de procedimientos puede llevar a la existencia de una relación de hechos probados en la sentencia recaída en la causa principal y otra en la sentencia civil de la pieza separada; lo que ha llevado a la doctrina a considerar diversidad de tesis ${ }^{90}$.

\footnotetext{
${ }^{86}$ Por ejemplo, porque el Ministerio Fiscal desistiera de la incoación del expediente cuando se tratase de delitos menos graves o faltas, «sin perjuicio de la tramitación de la correspondiente pieza de responsabilidad civil» (art. I8.I in fine LORPM, en su redacción original). Vid. VAQUER AloY, A., «La responsabilidad civil», cit., pág. I48.

${ }^{87}$ Cabe recordar que, aunque el art. 64.9 $9^{a}$ LORPM hiciese referencia a las Salas de Menores de los TSJ, fueron sustituidas por las Audiencias Provinciales por la LO 9/2000.

${ }^{88}$ DíAZ MARTíNEZ, M., «El régimen especial...», cit., pág. I7 (consulta online).

${ }^{89}$ VAQUER AloY, A., «La responsabilidad civil», cit., pág. I5O.

${ }^{\circ}$ Así, el criterio de la Circular FGE r/2000 es que «esos hechos acreditados, a que se refiere el artículo 64.IOa, lo son los de la sentencia penal del Juez de Menores y no los de la civil, habida cuenta de que esta no goza de fuerza de cosa juzgada y del principio de verdad formal y no material que impera en la jurisdicción civil». Para DíAz MARTinez, en cambio, los hechos acreditados deben ser los de la sentencia civil, debido al distinto contenido de las sentencias penal y civil, ya que la primera tiene por objeto la valoración de la conducta penal del menor, mientras que el objeto de la segunda es determinar si el hecho delictivo ha producido daños en
} 
A modo de resumen, puede concluirse que la LORPM creó un singular mecanismo procesal, calificado «de pieza separada», mediante el cual el proceso civil, pese a desarrollarse ante el mismo Juez de Menores que conocía de la pretensión penal, se tramitaba en procedimiento aparte del denominado «expediente principal» y se resolvía en una sentencia civil, la cual no producía efectos de cosa juzgada ${ }^{91}$.

La falta de efectividad de la sentencia, y la antieconomicidad procesal que suponía, conllevó que tanto Jueces como Fiscales ${ }^{92}$ solicitasen la derogación de esta regulación, proponiendo, de lege ferenda, el enjuiciamiento conjunto de las pretensiones penales y civiles en un único procedimiento, que se acomodase a las reglas generales que rigen el proceso principal y que finalice con sentencia que produzca plenos efectos de cosa juzgada material.

\section{III.4.2. Tratamiento procesal de la responsabilidad civil tras la LO 8/2006}

La Ley Orgánica 8/2006, de 4 de diciembre, reforma radicalmente los cauces procedimentales para exigir la responsabilidad civil en el proceso de menores. Mediante la modificación del art. 64 LORPM, que pasa de contener once reglas a cinco, - amén de otras modificaciones a lo largo del articulado- se establece un régimen en el que, a similitud de lo que sucede en el proceso penal de adultos, se produce la tramitación conjunta de las acciones civiles y penales y su resolución simultánea en una única sentencia. Se trata en este apartado de exponer las características de este nuevo régimen, por lo que obviaremos lo que se ha mantenido intacto.

Fase previa: personación de los perjudicados.- Al igual que en el régimen anterior, incoado el expediente por el Ministerio Fiscal, el Juez de Menores ordena abrir la pieza separada de responsabilidad civil (art. 64. I $^{\mathrm{a}}$ LORPM); con la diferencia de que, ahora, se debe tramitar de forma simultánea con el proceso principal (art. 64.2 $2^{\mathrm{a}}$ LORPM).

Tras la reforma, si el Fiscal desiste de la incoación del expediente penal con base en lo dispuesto en el art. I8 LORPM, o si el Juez de Menores acuerda el sobreseimiento por conciliación o reparación entre el menor y la víctima (art. I9 LORPM), el perjudicado no podrá tramitar separadamente la pieza de responsabilidad civil ante el Juzgado de Menores, sino que deberá presentar demanda ante el Juez civil competente ${ }^{93}$.

El Secretario Judicial debe notificar a quienes aparezcan como perjudicados su derecho a ser parte en la pieza de responsabilidad civil, estableciendo el plazo límite para el ejercicio de la acción. De la lectura combinada de esta regla con el art. 6r.I LORPM se

el patrimonio del perjudicado; «El régimen especial...», cit., pág. I7 (consulta online). Por último, otros autores defienden una tesis amplia que aboga por entender que «hecho probado» son todos los hechos, tanto los acreditados en la sentencia penal como en la civil; así VAQUER ALOY, A., «La responsabilidad civil», cit., pág. I5I y CUESTA MERINO, J.L., «La responsabilidad civil...», cit., pág. 343.

${ }^{9}$ Garciandía GonZÁleZ, P.M., «Tratamiento procesal...», cit., pág. 34.

$9^{2}$ Jornadas sobre la responsabilidad penal de los menores de Jueces y Fiscales de Menores, celebradas, respectivamente, en Madrid y Lanzarote en el año 200I. Vid. DíAz MARTínEZ, M., «El régimen especial...», cit., pág. I8 (consulta online).

${ }^{93}$ Insiste la Circular FGE I/2007, de 26 de noviembre, en que se tenga un especial cuidado en notificar la resolución recaída al perjudicado y se le advierta de la posibilidad de promover el ejercicio de acciones en vía civil. La preocupación del legislador por el perjudicado se refleja en la exigencia de notificación de la no incoación del expediente en dos preceptos distintos, puesto que así lo dispone tanto el art. I8.2 como el art. 4 LORPM. 
infiere que ese plazo será de un mes desde la apertura de la pieza, no quedando claro si es posible o no modificarlo ${ }^{94}$. El transcurso del plazo señalado para la personación es «preclusivo» y su incumplimiento provoca la imposibilidad de que el perjudicado comparezca en la pieza, debiendo hacerlo en su lugar el Ministerio Fiscal, de oficio ${ }^{95}$.

Personados en la pieza de responsabilidad civil los perjudicados y, en su caso, las compañías aseguradoras, se les facilitarán los datos para la reclamación civil ${ }^{96}$. Aunque la Ley sólo contempla la personación mediante escrito (art. 64.2 ${ }^{a}$ LORPM), nada impide que el perjudicado comparezca en persona o mediante Procurador con poder bastante ante el Juez de Menores y solicite su personación en calidad de parte activamente legitimada ${ }^{97}$; debiendo indicar las personas responsables del daño o perjuicio contra la que se pretende dirigir la demanda.

Por último, paralelamente al ofrecimiento de acciones a los perjudicados, el Secretario debe notificar al menor y a sus representantes legales su condición de posibles responsables civiles (art. 64.3 ${ }^{\mathrm{a}}$ LORPM).

Resolución sobre la condición de parte.- A la vista de lo manifestado en la personación por los perjudicados y responsables civiles, el Juez de Menores «resolverá sobre su condición de partes, continuándose el procedimiento por las reglas generales» (art. 64.4 ${ }^{\mathrm{a}}$ LORPM). Dicha resolución, al afectar al derecho de acceso a la jurisdicción como una de las vertientes del derecho fundamental a la tutela judicial efectiva (art. $24 \mathrm{CE}$ ), ha de ser motivada y, por tanto, revestir la forma de Auto ${ }^{98}$.

Este Auto puede acordar el archivo de la pieza de responsabilidad civil en los casos de renuncia o reserva de la acción, o disponer la condición de partes civiles de los perjudicados y responsables civiles. No establece la Ley plazo alguno para dictar esta resolución, entendiendo la Circular FGE i/2007 que «a la vista de que la propia esencia de la actividad instructora implica que puedan aparecer nuevos perjudicados y nuevos responsable civiles mientras se están practicando diligencias, podrá deferirse tal decisión a la propia fase intermedia, con la instrucción ya concluida» (apartado VIII.8).

Alegaciones $y$ juicio oral.- Una vez comparecidas las partes civiles en el proceso penal y admitida su personación por el Juez de Menores, dispone el art. 64.4 LORPM que el procedimiento continúa por las reglas generales.

Las partes pueden hacer valer sus derechos en el proceso de forma cumulativa con la pretensión penal, como en el caso del acusador particular y del menor imputado; o solamente respecto de la pretensión civil, para el resto de personas legitimadas pasivamente.

${ }^{94}$ La Circular FGE I/2000 entiende que es posible señalar un plazo de duración superior a un mes, pero nunca inferior, en virtud del principio pro actione. Igualmente, la Circular FGE I/2007 sostiene el incremento de esta flexibilización, de tal modo que es posible hacer coincidir la finalización del plazo de personación con el momento inmediatamente anterior a la formulación de los escritos de alegaciones (apartado VIII.6). Vid. GARCIANDÍA GonZÁlEZ, P.M., «Tratamiento procesal...», cit., pág. 37.

${ }^{95}$ SAP Córdoba, Sección $2^{\mathrm{a}}$, de 2I de febrero de 2005.

${ }^{96}$ Garciandía GonZÁleZ, P.M., «Tratamiento procesal...», cit., pág. 37.

${ }^{97}$ Morenilla Allard, P., El proceso penal del menor..., cit., pág. 207.

${ }^{8}$ Ibíd., pág. 208. 
La Ley no explica cuál ha de ser el papel de las partes civiles en la fase de instrucción, no obstante parece claro que, en tanto partes principales, tienen las mismas posibilidades de intervención que se prevén para las partes del proceso penal99.

Abierto el trámite de audiencia por el Juez de Menores, la pretensión civil se introduce en el denominado escrito de alegaciones (arts. 30 y 3I LORPM), para lo que se concederá un plazo común de cinco días hábiles, al igual que a las partes encargadas de incluir la resistencia. Contrariamente a lo previsto en la LEC, las partes han de proponer las pruebas que consideren pertinentes en sus escritos de alegaciones (art. 3I LORPM), las cuales no son otras que las previstas en el art. 299 y siguientes LEC. No obstante, se establecen límites a la admisión y práctica de los medios de prueba con base en la protección de la intimidad del menor, permitiéndose solamente el conocimiento de aquellos documentos «que tengan una conexión directa con la acción ejercitada» (art. 64.5) LORPM).

En cuanto al desarrollo de la audiencia, se dispone que deben comparecer las personas a quienes se exige responsabilidad civil, pero su inasistencia injustificada no constituye por sí misma causa de suspensión (art. 35.I in fine LORPM).

Por lo que se refiere a la conformidad, continuará el juicio adelante sólo respecto de la cuestión civil si el acuerdo no alcanza a ésta o no es aceptado por el actor civil o el tercero civil responsable (arts. 32 y 36.4 LORPM).

Sentencia, recursos y ejecución.- Finalizada la audiencia, el Juez de Menores ha de dictar sentencia única para los dos tipos de pretensiones, resolviendo sobre la responsabilidad civil derivada de delito o falta, con el contenido indicado en el art. II5 CP; esto es, estableciendo razonadamente lo que corresponda en relación con la restitución, reparación o cuantía de la indemnización solicitada por los perjudicados (arts. 38 y 39.I LORPM).

La sentencia podrá ser impugnada ante la Audiencia Provincial a través del recurso de apelación, produciendo efectos de cosa juzgada material una vez devenga firme, a diferencia de lo que ocurría en el régimen anterior.

El nuevo contenido del art. 64 LORPM suprime la remisión que se hacía a la LEC en materia de ejecución en su regla $9^{a}$, por lo que suscita la duda de si, una vez que la sentencia es firme, corresponde al Juez de Menores proveer, de oficio, lo necesario para la ejecución del fallo, o si, por el contrario, en aplicación de lo dispuesto en la LEC la ejecución debe tramitarse a petición de los intervinientes en la pieza separada de responsabilidad civil. La Circular FGE r/2007 entiende que decae la necesidad de petición de parte para iniciar la ejecución, debiendo llevarse a cabo de oficio por el Juzgado, por ser esta opción la más favorable para la víctima (apartado VIII.I4).

En fin, el art. 40.I in fine LORPM prevé que la posibilidad de que se suspenda la ejecución del fallo de la sentencia no afecta al pronunciamiento sobre la responsabilidad civil ex delicto.

${ }^{99}$ Dispone el art. 4 LORPM que aquéllos que se personen en el proceso «podrán desde entonces tomar conocimiento de lo actuado e instar la práctica de diligencias y cuanto a su derecho convenga»; vid. GARCIANDÍA GonZÁlEZ, P.M., «Tratamiento procesal...», cit., pág. 38. 
Hemos de concluir valorando positivamente las modificaciones introducidas en el régimen de responsabilidad civil por la reforma de 2006 , con las que se establece un sistema de acumulación de la acción penal con la civil que, sin duda, es más beneficioso para la víctima que el farragoso, defectuoso e incongruente procedimiento previsto inicialmente. No obstante, la Circular de la FGE I/2007 señala como esta nueva opción «aporta sin duda un plus de complejidad a la tramitación del expediente principal [...].Además, la adición de la pretensión civil a la tramitación de la pretensión sancionadoraeducativa implica sin duda un riesgo de generar dilaciones procesales».

\section{Breve referencia al enjuiciamiento de delitos cometidos por mayores y menores conjuntamente}

La regla general para el enjuiciamiento de un hecho delictivo atribuible a una pluralidad de partícipes, tanto en el ámbito general (arts. 300 y I7. ${ }^{\circ}$ LECrim) como en el de menores (art. 20.I LORPM), es su acumulación en un solo proceso. Pero, en el ámbito de la justicia de menores, podrían surgir problemas cuando los hechos delictivos fueran imputables a mayores y menores delincuentes en régimen de coautoría ${ }^{\text {10o }}$.

Por ello, la LORPM establece en este sentido una excepción a la acumulación subjetiva al prescribir el enjuiciamiento por separado y por sus respectivos órganos jurisdiccionales, de mayores y menores ${ }^{\text {Ior }}$. Y es que el art. I6.5 LORPM establece que «el Juez de Instrucción competente para el conocimiento de la causa, tan pronto como compruebe la edad de los imputados, adoptará las medidas necesarias para asegurar el éxito de la actividad investigadora respecto de los mayores de edad y ordenará remitir testimonio de los particulares precisos al Ministerio Fiscal». Esta previsión cubre en el momento de aprobarse la Ley un destacable vacío normativo, puesto que ni la LO 4/1992 ni su antecedente, la LTTM de I948, contenían en sus disposiciones ninguna previsión para los delitos o faltas cometidos conjuntamente por menores y mayores; aunque su regulación resulta, cuanto menos, insuficiente ${ }^{\text {To2 }}$.

La cuestión a dilucidar es qué efectos puede producir esta excepción de las reglas relativas a la acumulación por conexión subjetiva, teniendo presente que se trata de un enjuiciamiento de un mismo hecho con apariencia delictiva por dos órganos jurisdiccionales que actúan a través de cauces procedimentales diferentes, pudiendo llegarse no sólo a sentencias diferentes, sino incluso contradictorias ${ }^{\text {103 }}$. Y es que, en la práctica, siempre concluye primero el procedimiento de menores, lo que determina que la

${ }^{100}$ SAnZ HermidA, A.M., El nuevo proceso penal del menor, cit., pág. I46.

ror «En concreto, por el art. I6.5 LORPM que se menciona, pues de su tenor literal necesariamente resultaba en este caso un conocimiento de los hechos de apariencia criminal ante jurisdicciones separadas, al atribuirse inicialmente la participación en los mismos a una pluralidad de individuos de los que algunos eran mayores y otros menores de edad al tiempo de su producción»; STS de 29 de enero de 2013 (FJ $4^{\circ}$ ).

${ }^{102}$ SAla Donado, C., Proceso penal de menores: especialidades derivadas del interés de los menores y opciones de política criminal, Tesis dirigida por Teresa Armenta Deu, Universidad de Girona, Departamento de Derecho Público, 2002, pág. I96 (disponible en: http://www.tdx.cat/bitstream/handle/ı0803/7683/tcsd.pdf?sequence=I; fecha de consulta: 27. V.20I4).

${ }^{103}$ SAnZ Hermida, A.M., El nuevo proceso penal del menor, cit., pág. I47. 
condena o absolución afecte directamente al procedimiento ordinario ${ }^{\mathrm{ro4}}$, lo que plantea diversas cuestiones ${ }^{\text {105. }}$.

Se ha planteado la posible vulneración del principio de igualdad en aplicación de la Ley en aquellos casos en que, recaída sentencia en el proceso de menores con un resultado, la resolución del proceso penal de adultos llega sin embargo a uno diferente. La jurisprudencia ha entendido que sólo resulta alegable esta vulneración en aquellos supuestos en que unos mismos hechos son enjuiciados para imputados distintos en diferentes procesos por un mismo órgano jurisdiccional, pues los principios de independencia judicial y libre valoración de la prueba justifican de modo suficiente, en principio, que dos órganos jurisdiccionales pudieran llegar a conclusiones distintas en distintos procesos, sobre personas distintas, aunque se trate de unos mismos hechos $^{\text {rob }}$.Además, se debe tener en cuenta que, en la delimitación del objeto procesal, cuando hay una pluralidad de partes pasivas se entiende que procesalmente no existe ningún vínculo entre ellos ni deben correr idéntica suerte, por cuanto las acciones enjuiciadas son distintas para cada imputado ${ }^{\text {ro7 }}$.

Ahora bien, el respeto al principio de seguridad jurídica parece exigir que otros órganos jurisdiccionales que conozcan del mismo asunto asuman como ciertos los hechos declarados como tales en la primera resolución, sin embargo ello no puede suceder, puesto que en el orden penal no hay aspecto positivo en la cosa juzgada material penal ${ }^{108}$. No obstante, si en aplicación de la libre valoración de la prueba el tribunal que conoce con posterioridad llega a conclusiones diferentes, deberá incorporar a su decisión un «plus» de motivación que justifique adecuadamente las razones que marcan la diferencia ${ }^{\text {109 }}$. Sin embargo, sí se vulneraría el principio de seguridad jurídica cuando la contradicción existente entre las resoluciones del proceso de menores y de adultos afectase a la existencia o inexistencia del hecho delictivo ${ }^{\text {IIO }}$.

${ }^{104}$ Corcoy Bidasolo, M., «Responsabilidad penal de los menores. En particular, disfunciones en supuestos de participación delictiva conjuntamente con adultos», en AA.VV., Derecho penal y psicología del menor, $\mathrm{I}^{\mathrm{a}}$ edición, Granada, Comares, 2007, pág. 279.

${ }^{105}$ La Memoria del año 2012 de la FGE advertía de que «En las tres últimas Memorias de la FGE se viene plasmando la preocupación y los problemas que suscita, con carácter general, la instrucción y posterior enjuiciamiento por separado de aquellos asuntos en los que resultan imputados por los mismos hechos mayores y menores de edad. En tales casos se produce una auténtica instrucción paralela de las causas, ya que por un lado se lleva a cabo la tarea instructora por la Sección de Menores en el expediente de reforma incoado, mientras que tal investigación, en lo que atañe a los adultos, se lleva a cabo por el Juzgado de Instrucción que corresponda. La fase de enjuiciamiento posterior y las correspondientes vistas tienen idéntico carácter paralelo, ante el Juzgado de Menores, de una parte, y ante el Juzgado de lo Penal, Audiencia Provincial o Tribunal del Jurado, por lo que hace a los adultos».

${ }^{\text {ro6 }}$ STS de 3 de noviembre de I993.

${ }^{107}$ SANZ HERMIDA, A.M., El nuevo proceso penal del menor, cit., pág. I47.

${ }^{108}$ Por todas, STS de 2I de septiembre de I999: «cada proceso tiene su propia prueba, y lo resuelto en uno no puede vincular en otro proceso penal diferente, porque en materia penal no hay eficacia positiva de la cosa juzgada material, sólo eficacia negativa en cuanto que una sentencia firme anterior impide volver a juzgar a una persona por el mismo hecho».

${ }^{\text {rog }}$ STS de 29 de enero de 2013.

${ }^{\text {In }}$ «Es claro que unos mismos hechos no pueden existir ni dejar de existir para los órganos del Estado, pues a ello se oponen no sólo los principios elementales de la lógica jurídica y extrajurídica, sino el principio de seguridad jurídica constitucionalizado en el artículo 9.3», STC 77/I983, de 3 de octubre, FJ $4^{\circ}$ (BOE $n^{\circ} 266$, de 7 de noviembre de i983). 
A decir del propio Tribunal Supremo, en sentencia ya citada de 29 de enero de 2013 , recaída en el mediático caso de la joven sevillana Marta del Castillo, «quizá el mayor de los inconvenientes que deriva de esta situación es la duplicidad de actuaciones y diligencias de prueba, que provoca como efecto colateral la repetición de testimonios, con pérdida general de calidad de las pruebas que, sometidas al principio de inmediación, hayan de reiterarse ante una y otra jurisdicción y que, en el caso de las víctimas, incrementa además la victimización secundaria». Considera, de lege ferenda, que no sería inconveniente «una solución legisla tiva que resuelva disyuntivas procesales como la presente, compatibilizando un enjuiciamiento conjunto en sede de adultos en el que también se vele por los fines tuitivos y por las demás garantías que al menor reconoce la LORPM ${ }^{\text {III }}$.

Pese a que desde todos los estamentos parecían estar de acuerdo en la necesaria implantación de un nuevo sistema que permitiese la instrucción y el enjuiciamiento conjunto de aquellos hechos delictivos en que concurran como coimputados mayores y menores de edad, al menos en los delitos de máxima gravedad; lo cierto es que ni la reforma de la LORPM anunciada para el verano de 2012 se produjo, ni el borrador del nuevo Código Procesal Penal que vio la luz el pasado año incluye previsión alguna en este sentido.

III En esta misma línea, el Ministro de Justicia, Alberto Ruiz Gallardón, el 25 de enero de 20I2, en comparecencia ante la Comisión de Justicia del Congreso: «Señorías, en su preocupación y en la de los ciudadanos que ustedes representan está en estos momentos el incremento de la delincuencia cometida por menores. Creo que hay una sensación de que la Ley Orgánica de responsabilidad penal del menor no da respuesta suficiente a muchos problemas que se plantean en nuestra sociedad. Tenemos que diseñar una nueva regulación que además de las instituciones de protección y tutela jurídica del menor y discapacitados consiga adecuarlo con el derecho de familia a las nuevas realidades sociales favoreciendo la mediación y la corresponsabilidad de los padres. Conforme a otras normativas ya existentes en derecho comparado, les anuncio que para evitar casos que han posibilitado el doble enjuiciamiento cuando en un mismo delito grave concurre la participación de mayores y menores de edad pretendemos con la reforma unificar la investigación de hechos delictivos y proceder a un enjuiciamiento conjunto. Esto se hará sin merma alguna de los derechos del menor ya que se le aplicará a este siempre su normativa especial (Diario de Sesiones del Congreso de los Diputados $n^{\circ} 25$, de 25 de enero de 20I2, pág. I2). En igual sentido se expresa la FGE en la citada Memoria del año 20I2: «La solución ideal sería preconizar la sustanciación conjunta de los procesos, al modo y manera de otros ordenamientos (vgr. Chile), en cuanto a su instrucción y enjuiciamiento, lo que permite que para mayores y menores se llegue a conclusiones homogéneas respecto a la prueba y calificación jurídica de los hechos, con independencia de que para el menor o los menores se apliquen las normas, beneficios y medidas de la legislación de responsabilidad penal del menor». 